\title{
CRIMINAL LAW AND SENTENCING: WHAT GOES WITH FREE WILL?
}

\author{
R. George Wright $t^{*}$
}

\begin{abstract}
This Article notes that increasing numbers of scholars have argued that minimizing our collective belief in the possibility of genuine free will and moral responsibility would likely create a more humane, compassionate, enlightened, and generally progressive criminal justice and sentencing system. As it turns out, though, we must instead conclude that such optimism does not seem warranted. Beginning with Clarence Darrow's closing argument in defense of Leopold and Loeb, and then discussing the work of contemporary legal scholars, scientists, and philosophers, as applied in various criminal law contexts, the Article concludes on a skeptical note. Even if a culture views economic, structural, and institutional causes of crime with utmost seriousness, the more likely result of generally discounting free will and moral responsibility would involve criminal justice practices holding little appeal for most contemporary progressives and advocates of equality.
\end{abstract}

TABLE OF CONTENTS

INTRODUCTION 2

I. SOME INITIAL CONFLICTS OVER THE VALUE OF FREE WiLL

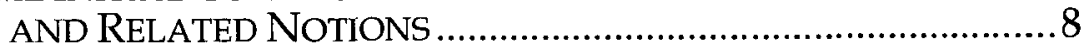

II. SOME ILlUSTRATIVE FORMS OF SERIOUS CRIMES .......................19

A. The Particularly Horrific Crime Cases .............................19

B. The Horrific Background and Horrific Crime Cases ........22

C. The Multiple Arrest, Multiple Conviction, and Recidivism Problem ........................................................26

D. The Drug and Addiction Cases ......................................31

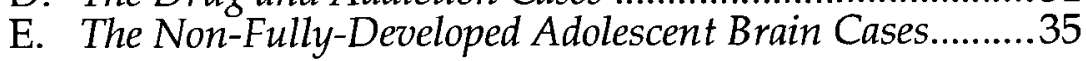

III. SOME CURRENT COSTS: OF CRIME, OF IMPRISONMENT, OF LIFE SENTENCES, AND OF THE DEATH PENALTY ....................39

CONCLUSION: THE QUESTION OF FORGIVENESS, MERCY, AND FREEDOM OF THE WILL .......................................................44

\footnotetext{
* Lawrence A. Jegen III Professor of Law, Indiana University Robert H. McKinney School of Law. The author thanks Angela M. Stackhouse for her invaluable assistance.
} 


\section{INTRODUCTION}

It is natural to wonder what criminal law and sentencing, broadly defined, will look like in the future. We can easily imagine that criminal law and sentencing might vary with the long-term health of the national economy, or lack thereof, with sustained trends in crime rates, with changes in technology, with basic changes in various cultural beliefs, or with the population's age profile or birth rates.

This Article will focus on the relation between criminal law and sentencing on the one hand and a widespread belief specifically in the reality of freedom of the will and related ideas on the other. The title of this Article may be read to ask what criminal justice practices "go with," in the sense of fit with, a belief in genuine freedom of the will. But, more starkly, the title also asks what else we should realistically expect to "go," in the sense of gradually disappear, if the idea of a robust libertarian free will and related ideas are actually minimized in popular and public thinking.

As we shall see, it is often argued that minimizing belief in free will and related notions is likely, on balance, to have desirable consequences for criminal law and sentencing. ${ }^{1}$ These benefits are often thought to include less vindictive or vengeance-tainted sentencing and case disposition, resulting in a more civilized and humane system overall. ${ }^{2}$ The point of this Article, however, is to suggest that such optimism is likely unfounded. ${ }^{3}$ The more likely result of minimizing our collective belief in a robust free will and other beliefs that depend upon a belief in free will would instead be unattractive to many humane current critics of the penological role of belief in free will. ${ }^{4}$

Among the classical ${ }^{5}$ and contemporary ${ }^{6}$ writers on free will, we find an expanding variety and increasing subtlety of approaches,

1. See infra notes $49-59$ and accompanying text.

2. See infra notes 52,54-59 and accompanying text.

3. See discussion infra Parts I-III.

4. See infra Parts I-III.

5. For a taste of some of the historic controversy, see, for example, ORIGEN, AN EXHORTATION TO MARTYDOM, PRAYER, AND SELECTED WORKS 94 (Rowan A. Greer trans., Paulist Press 1979) (233), where Origen endorses a standard view of freedom of the will based largely on our subjective experience. See AUGUSTINE, ON THE FREE CHOICE OF THE WILL bk. II, at 36 (Anna S. Benjamin \& L. H. Hackstaff trans., Bobbs-Merrill Co. 1964) (395) ("[I]f man did not have free choice of will, how could there exist the good according to which it is just to condemn evildoers and reward those who act rightly? What was not done by will would be neither evildoing nor right action. Both punishment and reward would be unjust if man did not have free will."); Bernard of ClairvauX, SelECTEd WORKS 176 (Gillian R. Evans trans., Paulist Press 1987) (explicitly linking free will and human dignity by stating "[m]an's dignity is his free 
such that no definition of any of the relevant key terms can be both concise and consensually acceptable to the sympathetic experts. Canvassing the full range of subtly differing perspectives is impossible. We shall instead begin to convey a flavor of some of the issues by focusing on Clarence Darrow's legendary closing argument in the defense of Nathan Leopold and Richard Loeb, delivered on Au-

will"); Thomas Hobbes, Leviathan 29 (J.C.A. Gaskin ed., Oxford Univ. Press 1998) (1651) (" $[\mathrm{I}] \mathrm{f}$ a man should talk to me of ... a free will; or any free, but free from being hindered by opposition; I should not say that he were in an error, but that his words were without meaning; that is to say, absurd.") (though Hobbes is not known for then arguing that a repudiation of free will would lead to a distinct liberalization of criminal law and sentencing); DAVID HUME, A TREatise of Human Nature 257-65 (David Fate Norton \& Mary J. Norton eds., Oxford Univ. Press 2000) (1740) (developing a compatibilist position in which free will in some sense is thought to be compatible with determinism); IMMANUEL KANT, CRITIQUE OF PRACTICAL REASON 26 (Mary Gregor ed. \& trans. Cambridge Univ. Press 1997) (1788) ("[A] will for which the mere lawgiving form of a maxim can alone serve as a law is a free will."); IMMANUEL KANT, CRITIQUe OF PURE REASON 366-80 (F. Max Muller ed. \& trans., Anchor Books 1966) (1781) (seeking to accommodate both the possibility of a transcendental free and reasonable will with the experience of universal empirical or phenomenal unbroken natural causal necessity); BENJAMIN LIBET, MIND TIME: THE TEMPORAL FACTOR IN CONSCIOUSNESS 156 (2004) (" $[T]$ he greatest gift which humanity has received is free choice. It is true that we are limited in our use of free choice. But the little free choice we have is such a great gift and is potentially worth so much for this itself is worthwhile living."); PICO DELLA MIRANDOLA, ORATION ON THE DIGNITY OF MAN (A. Robert Caponigri trans., Henry Regnery Co. 6th prtg. 1971) (1486) (classic discussion of the importance of freedom of the will); FRIEDRICH NIETZSCHE, TWILIGHT OF THE IDOIS AND THE ANTI-CHRIST 64 (R.J. Hollingdale ed. \& trans., Penguin Books 2003) (1889) (recognizing that, to a Nietzschean immoralist, free will is a ruse by the theologian to make persons accountable to and guilty before the theologian); ARTHUR SCHOPENHAUER, ON THE BASIS OF MORALITY 109-13 (E.F.J. Payne ed. \& trans., Bobbs-Merrill Co. 1981) (1841) (assuming universal determinism and necessity, despite our subjective experiences to the contrary, and speaking favorably of Kant's purported solution of distinguishing between an empirical or phenomenal world governed by determinism and necessity, and a separate "noumenal" or intelligible world of free will and genuine moral choice and responsibility); BENEDICT DE SPINOZA, ETHICS 62 (Edwin Curley ed. \& trans., Penguin Books 1996) (1677) ("In the mind there is no absolute, or free, will, but the mind is determined to will this or that by a cause which is also determined by another, and this again by another, and so on to infinity."); VOLTAIRE, PHILOSOPHICAL Dictionary 275, 278 (Theodore Besterman ed. \& trans., Penguin Books 2004) (1764) (stating, in dialogic format, "But once again, I . . do not possess free will? A: Your will is not free, but your actions are. You are free to act when you have the power to act. ..."); St. Thomas Aquinas, Summa Theologica: Free-will (Prima Pars, Q.83), NEW ADVENT, http://www.newadvent.org/summa/1083.htm (last visited Oct. 14, 2012) ("Free will is the cause of its own movement, because by free will man moves himself to act." ).

6. See discussion infra Part III. A good general rule is that, if a specific viewpoint on any free will related issue is even dimly imaginable, it has recently been endorsed in print. Combinations of viewpoints proliferate at a similar rate. One important substantive consideration is that a full defense of a robust, free-will-based criminal responsibility should be able to validate the idea that free will and responsibility can be manifested not only when an actor's motives or reasons are nearly equally balanced, but when one motive or reason dominates the others. But $c f$. MARK Balaguer, Free WiLl as an OPEn SCIENTIFIC Problem $71-75$ (2009) (focusing especially on what Balaguer refers to as "torn decisions"). For a review of Balaguer, see Tomis Kapitan, Book Review, 120 MiND 848, 848-52 (2011). 
gust 22, $1924 .^{7}$ Quoting extensively from Darrow, admittedly, cannot bring us up to speed on our contemporary science and philosophy. But a sense of Darrow's thinking serves to usefully introduce some basic issues with a starkness and clarity not easily found elsewhere.

For our purposes, Darrow begins his argument by noting that his clients were, at the time of the offense, eighteen and nineteen years of age. ${ }^{8}$ Today, neuroscientists would note that in most eighteen or nineteen-year-old males, the brain's pre-frontal lobes, involved in the exercise of judgment, are still in the process of development. ${ }^{9}$ Of course, assuming this to be so does not by itself indicate any sort of determinism or non-responsibility on the part of anyone whose prefrontal lobes have not yet fully developed. Further, most persons with still-developing brains and of dubious judgment manage to suppress any temptation to engage in kidnapping and murder, whether freely or not.

Darrow does not crucially ground his argument to the court on anything like age-related immaturity of judgment. He instead argues that, in accounting for his clients' actions, "[t]here are only two theories; one is that their diseased brains drove them to it; the other is the old theory of possession by devils." ${ }^{10}$ Darrow opts, unsurprisingly, for the former, "Your Honor . . . no human being could have done what these boys did, excepting through the operation of a diseased brain." ${ }^{11}$ Darrow further contends that his clients "killed ... because they were made that way." ${ }^{12}$

7. See Clarence Darrow, The Leopold \& Loeb Trial: Defendants' Closing Argument, in Trial by Jury 2010, at 623 (PL Litig. \& Admin. Practice, Order No. 23283, 2010), [hereinafter Darrow, Closing Argument], available at http://law2.umkc.edu/faculty/projects/ftrials/leoploeb/ darrowclosing.html. (last visited Oct. 7, 2012); see also ClARENCE DARROW, CRIME: ITS CAUSE AND TREATMENT (1922), available at www.gutenberg.org/catalog/world/readfile?fk_files= 1483105 (2004). Leopold and Loeb, both legal minors at the time of the offense, were socially prominent and well-educated Chicago residents charged and ultimately convicted after a bench trial of an apparently gratuitous kidnapping and murder. They were sentenced to life plus ninety-nine years, but Loeb was killed in prison, and Leopold was released on parole after serving thirty-three years. See generally HAL HIGDON, LEOPOLD AND LOEB: THE CRIME OF THE CENTURY (1999); Edward J. Larson, An American Tragedy: Retelling the Leopold-Loeb Story in Popular Culture, 50 AM. J. LEGAL HIST. 119 (2008); Paula S. Fass, Book Review, 28 LAW \& HIST. REV. 271, 271-73 (2010) (reviewing SIMON BAATZ, FOR THE THRILL OF IT: LEOPOLD, LOEB, AND THE MURDER THAT SHOCKED CHICAGO (2008)).

8. See Darrow, Closing Argument, supra note 7, at 627.

9. See infra Part II.E.

10. Darrow, Closing Argument, supra note 7, at 631.

11. Id. at 632 .

12. Id. 
Even at this early point, some basic questions arise. Would all significantly and relevantly diseased brains absolve an actor from moral or legal responsibility? What is the relationship between a diseased brain and other sorts of serious crimes, including crimes involving substantial foreseen profit to the perpetrator? Could a defendant still be absolved from responsibility if he or she was not "made that way"? Could a criminal act, more specifically, have been causally determined, such that blaming the defendant is inappropriate, if the defendant was not "made that way," as Darrow uses the term?

It becomes clearer that Darrow intends a broad argument when he then argues that " $[\mathrm{s}]$ cience has been at work, humanity has been at work, scholarship has been at work, and intelligent people now know that every human being is the product of the endless heredity back of him and the infinite environment around him."13

Although Darrow is unwilling to point to any particular causal condition as an explanation for Loeb's actions, he is also clearly unwilling to impute moral responsibility in the sense of personal blame:

Is he to blame for what he did not have and never had? Is he to blame that his machine is imperfect? Who is to blame? I do not know. I have never in my life been interested so much in fixing blame as I have in relieving people from blame. I am not wise enough to fix it. ${ }^{14}$

Darrow then speculates, "It may be defective nerves. It may be a defective heart or liver. It may be defective endocrine glands. I know it is something. I know that nothing happens in this world without a cause." ${ }^{\prime 15}$

Doubtless, Darrow intends the idea of cause here to exclude the genuinely free and decisive personal or originating agency of the actor. His reference to various bodily organs may seem curious because Darrow has already attributed the crime in question to diseased brains. ${ }^{16}$ But Darrow may be suggesting that a defective bodily organ causally contributed to a diseased brain, that a diseased brain caused some relevant organ defect, or both. The links in the

\footnotetext{
13. Id. at 640 .

14. Id. at $639-40$.

15. Id. at 640.

16. See supra text accompanying notes 10-11.
} 
causal chain involving the crime are, in Darrow's view, perhaps multiple and complex. ${ }^{17}$

Darrow recognizes that his clients would hardly qualify as economically or culturally deprived, but this does not affect his endorsing a broader determinism. ${ }^{18}$ Wealth, as well as poverty, can sometimes help send a person down a socially disapproved path. ${ }^{19}$

More deeply, Darrow doubts that the idea of an irreducible mind can be brought in to allow us to escape from extended and inescapable chains of causal determinism. With regard to the idea of a distinct, non-corporeal mind, Darrow concludes that " $[w]$ hether it exists or not no one can tell. It cannot be found as you find the brain. Its relation to the brain and the nervous system is uncertain. It simply means the activity of the body, which is coordinated with the brain." ${ }^{20}$

Although Darrow's own claims, in some respects, may not be entirely consistent with one another, the general drift of his thinking seems clear enough for our own limited purposes. As Darrow concludes, we are not our own parents. ${ }^{21}$ More broadly, "[n]ature is strong and she is pitiless. She works in her own mysterious way, and we are her victims. We have not much to do with it ourselves. Nature takes this job in hand, and we play our parts."22

These remarks, when taken together, give us some sense of Darrow's broad, non-technical causal determinism, particularly in the criminal law and sentencing context. But our main concern, overall, is for the relationship between belief in anything like determinism or free will, and the ways in which the law and public policy characterize and respond to persons who may pose a threat to the security and basic well-being of other persons. And here, too, Darrow gives us some indication of the way in which his own belief in causal determinism leads him, and should, in his view, lead others.

17. See supra text accompanying notes 13-15.

18. See Darrow, Closing Argument, supra note 7 at 630-31. It is entirely reasonable to argue, in contrast, that much ordinary crime is ultimately caused largely, if not entirely, by systemic and structural inequalities and barriers to opportunity and that the best way to address such crimes is to remedy such inequalities and remove such barriers. With this argument, we certainly have no objection. Our concern below is that there can be no guarantee, post-free will, that relevant publics will consider such an approach to be the most cost-effective or the most utility-enhancing approach for preventing criminal behavior.

19. Id. at 643 .

20. Id. at 642 .

21. Id. at 645 .

22. See id. It is unclear how much fundamental dignity we should associate with hapless, perpetual victimhood. 
Throughout his argument for some form of determinism, Darrow makes presumably related normative judgments. ${ }^{23}$ Darrow links determinism, sickness, and humane treatment. ${ }^{24}$ In particular, Darrow argues that his clients are "two young men who should be examined in a psychopathic hospital and treated kindly and with care. ${ }^{25}$ More broadly, Darrow asks:

Do I need to argue to Your Honor that cruelty only breeds cruelty? That hatred only causes hatred; that if there is any way to soften this human heart which is hard enough at best; if there is any way to kill evil and hatred and all that goes with it, it is not through evil and hatred and cruelty; it is through charity, and love, and understanding. ${ }^{26}$

Darrow concludes the substance of his closing argument on behalf of Leopold and Loeb by declaring that:

I am pleading for the future; I am pleading for a time when hatred and cruelty will not control the hearts of men. When we can learn, by reason and judgment and understanding and faith, that all life is worth saving, and that mercy is the highest attribute of man. ${ }^{27}$

Clarence Darrow was, of course, not a technical philosopher, and thus was not interested in the remarkably burgeoning variety of increasingly refined approaches to determinism, randomness, responsibility, and free will, as those terms are now variously defined and understood. ${ }^{28}$ Nor was Darrow a technical theorist in the sense of

\footnotetext{
23. Id. at 634-38.

24. Id.

25. Id. at 634 (emphasis added).

26. Id. at 638 .

27. Id. at 664; see also discussion infra Part III (discussing the possible meanings of mercy and the relationship between mercy and determinism). For what amounts to a traditionalist response to Darrow, see generally C.S. Lewis, The Humanitarian Theory of Punishment, 6 RES JUDICATAE 224 (1953), available at www.angelfire.com/pro/lewiscs/humanitarian.html (last visited Oct. 4, 2012).

28. The literature on these questions is now vast and increasingly fragmented and, thus, not subject to fair and concise summary. Representative leading approaches, cited below, will allow the reader to construct her own response. For merely one example of the beginnings of a typology, with some suggested definitions, see Peter van Inwagen, How to Think About the Problem of Free Will, 12 J. ETHICS 327, 330 (2008), where the author seeks to define terms, including determinism, indeterminism, compatibilism, incompatibilism, libertarianism in the free will context, hard determinism, soft determinism, and the idea of moral responsibility. For a discussion of van Inwagen's own free will "mysterianism," see generally Seth Shabo, Why Free Will Remains a Mystery, 92 PAC. PHIL. Q. 105 (2011).
} 
seeking to exhaustively catalog and appraise all possible approaches to criminal justice, sanctioning, and punishment. ${ }^{29}$ This Article, for the sake of manageability, will follow Darrow in these respects. On the initial basis of something like Darrow's thinking, we can begin to examine the possible costs and benefits, direct and indirect, of disavowing free will and related ideas in criminal justice and sentencing.

\section{SOME INITIAL CONFLICTS OVER THE VALUE OF FREE WILL AND RELATED NOTIONS}

Many writers, who we may call "compatibilists," have sought to reconcile some form of determinism with some form of free will. ${ }^{30}$

\footnotetext{
Non-philosophers should be aware that many theorists hold that at least, in some sense of the term, freedom of the will is compatible with one or more conceptions of determinism. Our accepting or endorsing of our own actions is supposed to make, on some such accounts, a decisive difference even in a determined world. See generally JOHN MARTIN FISCHER \& MARK RAVIZZA, RESPONSIBILITY AND CONTROL: A THEORY OF MORAL RESPONSIBILITY 11 (1998); Harry G. Frankfurt, Freedom of the Will and the Concept of a Person, 68 J. PHIL. 5 (1971); Seth Shabo, Where Love and Resentment Meet: Strawson's Intrapersonal Defense of Compatibilism, 121 PHIL. REV. 95 (2012). For a much "thinner" version of compatibilism in which free will is thought to require determination of some choices by our own motivated, internal, revisable deliberations,
} See Nicholas ResCher, FREE WiLl: A PHILOSOPHICAL RE-APPRAISAL 126-27 (2009).

A further complication is that, "[i]n law, responsibility is not a single concept, but it is rather a syndrome of at least six concepts." Nicole A. Vincent, On the Relevance of Neuroscience to Criminal Responsibility, 4 CRIM. L. \& PHIL. 77, 84 (2010); see also T.M. Scanlon, Varieties of Responsibility, 90 B.U. L. REV. 603, 603-04 (2010) (distinguishing personal, moral, and substantive responsibility).

29. For a mere beginning at such a task, see, for example, Manuel Escamilla-Castillo, The Purposes of Legal Punishment, 23 RATIO JuRIS 460, 460 (2010), and, judicially, Graham v. Florida, 130 S. Ct. 2011, 2027-30 (2010) (cited in State v. Andrews, 329 S.W.3d 369, 379-81 (Mo. 2011) (en banc) (Wolff, J., dissenting)), where the court refers to "retribution, deterrence, incapacitation, and rehabilitation" as penological goals.

30. See, e.g., FISCHER \& RAVIZZA, supra note 28, at 240-59; Frankfurt, supra note 28, at 20; Joshua Greene \& Jonathan Cohen, For the Law, Neuroscience Changes Nothing and Everything, 359 PhIL. TRANSACTIONS ROYAL SOC'Y LONDON B 1775, 1783-84 (2004). Beyond various forms of compatibilism itself, there are even attempts to reconcile compatibilism and incompatibilism. See Bruce N. Waller, A Metacompatibilist Account of Free Will: Making Compatibilists and Incompatibilists More Compatible, 112 PHIL. STUD. 209, 211 (2003).

It is fair to say that there is no current consensus on how reconciling standard notions of determinism and free will is to be done clearly and precisely without crucially diluting the most familiar meanings of either determinism or free will. It is also fair to say that there is no consensus on how traditional free will is supposed, precisely, to work and to fit in with the world around us. For many, a universal determinism, perhaps with elements of random chance, may seem easier to envision than either compatibilism or libertarian free will. But this, too, may be an illusion. See Nancey Murphy, Nonreductive Physicalism and Free Will, METANEXUS INSTITUTE, $\S 4$ (May 28, 2008), http://www.metanexus.net/archive/ 
Other writers more directly cast severe doubt on the possibility of any robust, meaningful free will, partly through their minimalist characterizations of what it means to be human.

The physicist Stephen Hawking, for example, among the latter, declared that " $[t]$ he human race is just a chemical scum on a moderate-sized planet. ${ }^{\prime \prime 1}$ Presumably, chemical scum is incapable of robust free will, genuine moral responsibility, dignity in the relevant and most fundamental sense, genuine moral choice, blameworthiness or genuine praiseworthiness, ongoing selves, genuine personhood, at least some forms of moral thought, or full autonomy. This should give us some pause. Hawking's fellow physicist, Paul Davies, comments that " $[\mathrm{m}]$ ost physicists and cosmologists would echo Hawking and regard life as a trivial, accidental embellishment to the physical world, of no particular significance in the overall cosmic scheme of things." ${ }^{32}$

In a somewhat different characterization, but with similar implications for free will, the neurobiologist Anthony R. Cashmore concludes that "as living systems we are nothing more than a bag of chemicals." ${ }^{33}$ The philosopher John Gray has opined, to similar ef-

conference2008/articles/Default-id=10501.aspx.html ("[W]e no longer know how to define determinism.").

It is doubtful that any overall approach to free will or its absence can be specified with clarity and thoroughness. This Article does not assume the truth or falsity or even the coherence of compatibilism, libertarian free will, determinism, or any of the proliferating subtle variations thereon. It instead focuses on the likely long-term social and legal consequences of the adoption, so far as practical, of particular views.

31. David Deutsch, The Fabric of Reality: The SCIENCE OF Parallel Universes and ItS IMPLICATIONS 177-78 (Allen Lane The Penguin Press 1997); see also PAUL DAVIES, THE GOLDILOCKS ENIGMA: WHY IS THE UNIVERSE JUST RIGHT FOR LIFE? 222 (Houghton Mifflin Co. 2008).

32. DAviES, supra note 31, at 222; see also FRANCIS CRICK, THE ASTONISHING HYPOTHESIS: THE SCIENTIFIC SEARCH FOR THE SOUL 3 (Touchstone 1995) ("You, your joys and your sorrows, your memories and your ambitions, your sense of personal identity and free will, are in fact no more than the behavior of a vast assembly of nerve cells and their associated molecules.... You're nothing but a pack of neurons.") (internal quotation marks omitted). Further, see the contrasting view of ALVIN PLANTINGA, WHERE THE CONFLICT REAlly LIES: SCIENCE, RELIGION, AND NATURALISM 322-23 (Oxford Univ. Press 2011) (quoting Crick). See generally AlEx RosENBERG, THE ATHEIST'S GUIDE TO REALITY: ENJOYING LIFE WITHOUt ILLuSIONS (W. W. Norton \& $C 0.2011)$.

33. Anthony R. Cashmore, The Lucretian Swerve: The Biological Basis of Human Behavior and the Criminal Justice System, 107 PNAS 4449, 4504 (2010), available at www.pnas.org/cgi/doi/

10.1073/pnas.0915161107. Professor Cashmore explicitly refers to free will as an illusion, and he is hardly alone among contemporary scientists and philosophers in doing so. Compare id., with OWEN Flanagan, THE REAlLy HaRd PROBlem: MEANING IN a Materialist WORLD 3036 (MTT Press 2007) (rejecting the idea of libertarian free will), ROSENBERG, supra note 32, at 236-38, and Daniel M. WeGNer, The Illusion of Conscious Will 2-3 (MIT Press 2002). Wegner argues more broadly that: 
fect, that "[f]or Gaia, human life has no more meaning than the life of the slime mould." ${ }^{34}$

The imagery of a human as a complex organic robot or a complex sentient puppet also arises in the philosophy literature, ${ }^{35}$ and casts similar doubt on the possibility of genuine free will, and on genuine moral and many forms of criminal responsibility. It is often argued

[1]t seems to each of us that we have conscious will. It seems we have selves. It seems we have minds. It seems we are agents. It seems we cause what we do. Although it is sobering and ultimately accurate to call all this an illusion, it is a mistake to conclude that the illusory is trivial. On the contrary, the illusions piled atop apparent mental causation are the building blocks of human psychology and social life.

WEGNER, supra note 33, at 341-42. For a detailed, exceptionally thoughtful, and remarkably subtle treatment of those and related issues, see SAUL SMILANSKY, FREE WILL AND ILLUSION 97, 277-88 (2002) [hereinafter ILLUSION] and Saul Smilansky, Free Will: From Nature to Illusion, 101 PrOC ARISTOTELIAN SOC'Y 71, 88-94 (2001) [hereinafter From Nature to Illusion]. Smilansky's remarkably untidy ultimate conclusion is that:

[O]ur priority should be to live with the assumption of libertarian free will although there is no basis for this other than our very need to live with this assumption; but as we cannot accept this way of seeing things, and confront dangers to our beliefs, motivated illusion must play a central role in our lives.

ILLUSION, supra note 33 , at 231 . Why should we expect this assumedly groundless "belief" in free will to remain stable over time, even as more of us appreciate, more deeply and in more contexts, its illusory character? Illusory beliefs can admittedly have their pragmatic uses. See DANIEL DENNETT, CONSCIOUSNESS EXPLAINED 162-64 (1991). Even assuming the genuine coherence of such approaches, it is hard to see such illusionist approaches, once they are widely and consistently internalized, as pragmatic in anything but name.

The rise of several schools of moral factionalism raises some related problems. For an introduction to the moral fictionalist literature, see generally RICHARD JOYCE, THE MYTH OF MORALITY 206-31 (2001); MARK ELI KALDERON, MORAL FICTIONALISM (2005); and Terence Cuneo \& Sean Christy, The Myth of Moral Fictionalism, in NEW WAVES IN METAETHICS 85, 85-102 (Michael Brady ed., 2011).

For a statement of the loosely related position that typical claims about free will and moral responsibility are actually incoherent and thus unreal, and can be meaningful only as subjective or attitudinal terms without objective truth or falsity, see RICHARD DOUBLE, THE NONREALITY OF FREE WILL 139-44 (1991) and Richard Double, Honderich on the Consequences of Determinism, 56 PHIL. \& PHENOMENOLOGICAl Res. 847, 848 (1996). Actually, though, if we are all genuinely without free will and its associated capacities and statuses, it is hard to see why our noticing these facts and their implications should be taken as genuinely demeaning. If there is a sense in which the idea of the demeaning simply cannot apply to human beings as we are, we cannot sensibly view that fact as, in the same sense, demeaning.

34. JOHN GRAY, STRAW DOGS: THOUGHTS ON HUMANS AND OTHER ANIMALS 33 (Farrar, Strauss \& Giroux 2007) (2002). Gray's breakdown has been quoted and critiqued in Raymond Tallis, What Neuroscience Cannot Tell Us About Ourselves, 29 THE NEw ATLANTIS 3, 4 (2010), available at www.thenewatlantis.com/publications/what-neuroscience-cannot-tell-usabout-ourselves.

35. See Joshua D. Greene, Social Neuroscience and the Soul's Last Stand, in SOCIAL NeUROSCIENCE: TOWARD UNDERSTANDING THE UNDERPINNINGS OF THE SOCIAL MIND 263, 264 (Alexander Todorov et al. eds., 2011), available at http://www.wjh.harvard.edu/ jgreene ("Officially, we scientists already know (or think we know) that ... we are simply complex biological machines."). 
that there can be no genuine moral responsibility without freedom of will, ${ }^{36}$ and that free will is also typically required for serious culpability within the realm of criminal law. ${ }^{37}$

Chemical scum, bags of chemicals, slime moulds, complex, organic robots, and sentient puppets may lack the capacity for free will and for moral and criminal responsibility. Free will and full responsibility may also be linked to some arguably crucial forms of human dignity ${ }^{38}$ Free will may, on some views, also be necessary even for

36. See, e.g., Gardar Arnason, Neuroscience, Free Will and Moral Responsibility, 15 TRAMES 147, 147 (2011); Randolph Clarke, Free Will and the Conditions of Moral Responsibility, 66 PHIL. STUD. 53, 55 (1992) ("[F]ree will is a necessary condition of being morally responsible for what one does."); Paul Edwards, Hard and Soft Determinism, in DETERMINISM AND FREEDOM IN THE AGE OF MOdERn SCIENCE 117, 125 (Sidney Hook ed., Collier Books 1961) ("From the fact that human beings do not ultimately shape their own character, . . . it follows that they are never morally responsible.").

For a sophisticated, well-nuanced denial of both free will and real or ultimate moral responsibility, see GALEN STRAWSON, FREEDOM AND BELIEF 80-125, 269-73 (rev. ed. 2010). But see R. JAY WALLACE, RESPONSIBILITY AND THE MORAL SENTIMENTS 7-8 (1994) (arguing for responsibility as a matter of rational powers and control rather than freedom of will); Harry G. Frankfurt, Alternate Possibilities and Moral Responsibility, 66 J. PHIL. 829, 838-39 (1969) (rejecting a robust view of libertarian free will, but seeking to retain moral responsibility). See generally Michael S. GaZZaniGa, WHo's IN CHARge? FREE Will AND THE SCIENCE OF THE BRAIN (2011) (discussing the idea of the universe as determined, with the mind and brain mutually constraining one another, but with responsibility still emerging as a deep social-interactional artifact, rather than as a property of brains); Michael S. Gazzaniga, Neuroscience in the Courtroom, 304 SCI. AM. 54, 59 (2011) ("[P]eople, not brains, commit crimes.").

For yet another interesting variant, see BRUCE N. WALLER, AGAINST MORAL RESPONSIBILITY 20, 44-45, 247-51, 294 (2011) (rejecting moral responsibility and moral desert in criminal and non-criminal contexts on the basis of a scientific or naturalist world view, while seeking to retain a naturalized view of free will, some elements of morality, and a more humane, progressive criminal justice system emphasizing structural and systemic inequalities, environment and circumstances, causal histories, restorative and rehabilitative justice, and enlightened behavioral-shaping). As Professor Waller points out, "if no one has moral responsibility, then lack of moral responsibility does not set one apart." Id. at 251. For a review of Waller's book, see Saul Smilansky, Book Review, Notre Dame PHIL. Rev. (Apr. 4, 2012), http://ndpr.nd.edu/news/29997-against-moral-responsibility.

37. See, e.g., Arnason, supra note 36, at 147. But see Stephen J. Morse, Determinism and the Death of Folk Psychology: Two Challenges to Responsibility from Neuroscience, 9 MINN. J.L. SCI. \& TECH. 1, 2 (2008) ("[F]ree will is not a criterion of . . criminal responsibility.").

38. See RANDOLPH ClaRkE, LiBERTARIAN ACCOUNTS OF FREE WILL 5 (2003) ("We generally think that our having free will (if indeed we have it) is partly constitutive of human dignity."); Clarke, supra note 36, at 54; see also B.F. SKINNER, BEYOND FREEDOM AND DIGNITY 25 (1971) (linking freedom and dignity with purportedly discredited ideas of personal autonomy and genuine responsibility). With far greater nuance, see Saul Smilansky, Free Will and Respect for Persons, 29 MIDWEST STUDS. IN PHIL. 248, 261 (2005) where Smilansky states, "[a]t the depths, the libertarian illusion is constitutive of our very humanity; it is a condition for deep selfrespect and for respect for persons." 
genuinely "rational decision-making." ${ }^{39}$ The philosopher John Searle has thus suggested that "you can't make sense of rational decisionmaking and acting except under the presupposition of free will." 40

Even further, it has been argued that, without freedom of the will, we lack adequate grounds for seeing political freedom as intrinsically valuable. If we lack free will, we may still find governmental restraints to be unduly costly, inefficient, painful, or otherwise leading to undesired consequences. But without the reality of (and the belief in) free will, political freedom "would not be recognizable to us as an important value." ${ }^{41}$ If we are crucially similar to, say, complex, sentient, organic robots, we would presumably want to be programmed by whichever programmer is best, in terms of delivering the biggest net payoffs in the consequences we sensibly care about and, specifically, in whatever ways we can be spared unpleasantness and gratified. But this is some distance from distinctively valuing political liberty. ${ }^{42}$ The best programming for the most desired consequences need not involve our making choices under conditions of political freedom. It is even possible that the most gratifying long-term programming may involve the deliberate programming of illusions we cannot recognize to be illusions.

The loss of a belief in a genuine free will might also be caused in part by, or contribute to, a diminishing sense of any meaningful, unified, continuing self. Denying the existence of such a self, the philosopher Daniel Dennett has argued that "[c]onscious human minds are more-or-less serial virtual machines implemented-

39. SUSAN BLACKMORE, CONVERSATIONS ON CONSCIOUSNESS 198, 205 (2007) (conversation with John Searle); see also Bruce N. Waller, Denying Responsibility Without Making Excuses, 43 AM. PHIL. Q. 81, 82-83 (2006) (citing several writers linking free will to rationality, to moral responsibility, and even to moral status and morality itself).

40. BLACKMORE, supra note 39, at 205; cf. Antony Duff, Psychopathy and Answerability, in RESPONSIBILITY AND PSYCHOPATHY: INTERFACING LAW, PSYCHIATRY, AND PHILOSOPHY 199, 203-04 (Luca Malatesti \& John McMillan eds., 2010) (“[T]o understand responsibility as answerability is to understand it as a matter of reasons-responsiveness."); see also Peter Westen, Getting the Fly out of the Bottle: The False Problem of Free Will and Determinism, 5 BUFF. CRIM. L. REV. 599, 636 (2005) (discussing reasoned reflection, judgment, and knowledge of truth as dependent upon a robust free will). How a complex, sentient machine could be moved precisely by a reason itself seems inescapably mysterious.

41. ThOMAs PinK, Free WILl: A Very SHOrT InTRODUCTION 4 (2004); see also Goran DuusOtterstrom, Freedom of Will and the Value of Choice, 37 SOC. THEORY \& PRAC. 256, 256 (2011) (suggesting that "the reasons to value choice depend on our having (libertarian) free will"). But see DANIEL DENNETT, FREEDOM EVOLVES 169 (2003).

42. See generally HENRY DAVID THOREAU, CIVIL DisOBEDIENCE (1849), available at http://thoreau.eserver.org/civil.html (suggesting that political liberty entails free will and free action). 
inefficiently - on the parallel hardware that evolution has provided for us." ${ }^{43}$ Doubting or abandoning belief in free will thus may "undermine the sense of self as agent."

Finally, it has been suggested that disbelief in free will may also lead to an increase in a range of antisocial or exploitive behaviors currently thought to be morally undesirable $e^{45}$ or economically unproductive. ${ }^{46}$ But it seems speculative and premature, at best, to rely

43. DANIEL C. DENNETT, CONSCIOUSNESS EXPLAINED 218 (1991), quoted and critiqued in Charles Taliaferro, The Soul of the Matter, in THE SOUL HYPOTHESIS 26, 31-32 (Mark C. Baker \& Stewart Goetz eds., 2011); see also DANiEL C. DENNETT, FREEDOM EVOLVES 2-3 (2003) ("We are each made of mindless robots and nothing else, no non-physical, non-robotic ingredients at all. The differences among people are all due to the way their particular robotic teams are put together, over a lifetime of growth and experience."). Dennett has also argued that a human is "a particular sort of ape infested with memes." Susan Blackmore, The Evolution of Meme Machines, DR. SUSAN BLACKMORE, http://www.susanblackmore.co.uk/Conferences/

Ontopsych.htm (last visited Oct. 14, 2012); see also NicHOLAS HUMPHREY, SOUL DUST: THE MAGIC OF CONSCIOUSNESS 204 (2011) ("Consciousness is an impossible fiction, or perhaps better said, a fiction of the impossible."); Dean Mobbs et al., Law, Responsibility, and the Brain, 5 PLOS B1OLOCY 693, 695 (2007) ("Most neuroscientists hold that 'minds are simply what brains do."') (citation omitted).

44. See Kathleen D. Vohs \& Jonathan W. Schooler, The Value of Believing in Free Will: Encouraging a Belief in Determinism Increases Cheating, 19 PSYCHOL. SCI. 49, 54 (2008); see also ROSENBERG, supra note 32, at 19 ("The love of stories comes to us in a package that ... includes the illusion of free will ... [and] the fiction of an enduring self ...."). For further discussion of the possible link between free will and personhood, see CLARKE, supra note 38 , at 12, where Clarke states that "human agents are persons even if determinism is true," and JOHN MARTIN FISCHER, THE METAPHYSICS OF FREE WLL 3 (1994). Clarke's view may itself depend ultimately on redefining what it means to be an agent or a person. See discussion infra note 49; see also Escamilla-Castillo supra note 29, at 460 (discussing the broader debate over the coherence of compatibilism); FLANAGAN, supra note 33 at 36 ("Agency is real, but libertarian free will is an illusion."); Galen Strawson, On "Freedom and Resentment," in Perspectives ON MORAL ReSPONSIBILITY 67, 80 (John Martin Fischer \& Mark Ravizza eds., 1993).

45. There may be a sense in which abandoning the idea of free will and moral responsibility-along with the ideas of a unified self, autonomy, and rational decision-making-logically requires abandoning some familiar elements or understandings of morality itself. For an extreme view that rejects free will and morality, see ROSENBERG, supra note 32 , at 3 . We would not view mere complex, sentient, organic robots as full or genuine moral actors. See, e.g., Waller, supra note 39, at 82-83. See generally WALLER, supra note 36 (seeking to retain a number of progressive, liberating aspects of morality in the absence of moral desert and responsibility). For discussion specific to undesirability, see Arnason, supra note 36, at 148; Julian B. Rotter, Internal Versus External Locus of Control of Reinforcement: The Case History of a Variable, 45 AM. PSYCHOLOGIST 489, (1990), available at http://mres.gmu.edu/readings/PSYC557/

Rotter1990.pdf; and Vohs \& Schooler, supra note 44, at 53-54.

46. See, e.g., From Nature to Illusion, supra note 33, at 85; see also Arnason, supra note 36, at 148 (citing the experimental literature). Although it is refreshing to be able to point to actual empirical studies on these latter issues, we should hesitate to draw conclusions as to the values and disvalues of (belief in) free will based on limited and rather artificial experimental laboratory studies. This is particularly so when we must extrapolate from the beliefs of particular individuals to a much broader social condition in which belief in free will and related concepts is minimized to the greatest degree realistically possible. The fact that the participants in 


\section{on the limited currently available empirical or laboratory studies for such purposes. ${ }^{47}$ \\ But suppose we were indeed to minimize our collective belief in a robust free will, ${ }^{48}$ along with our belief in crucial forms of moral re- sponsibility, autonomy, personhood, fundamental dignity, some traditional forms of moral judgment, and the self. ${ }^{49}$ Today, it is}

such studies live in a culture that still validates and endorses the possibility of free will in many instances may affect current laboratory results.

47. See discussion supra note 46 .

48. For a concise summary of the debate over other concepts and values that may in some way depend upon a robust free will, see ROBERT KANE, THE SIGNIFICANCE OF FREE WILL 80 (1996), where Kane suggests that a belief in "underived origination" is necessary for "(1) genuine creativity; (2) autonomy ... or self-creation; (3) true desert ... ; (4) moral responsibility in an ultimate sense; (5) being suitable objects of . . . admiration, gratitude, resentment and indignation; (6) dignity or self-worth; (7) a true sense of individuality or uniqueness as a person; (8) life-hopes requiring an open future; (9) genuine (freely given) love and friendship ...; and (10) the ability to say in the fullest sense that one acts of one's own free will." Of course, it is always possible to define, or re-define, each of these terms in some attenuated, minimalist, evacuated, reduced, unambitious, non-realist, or otherwise deflated sense so that a complex, sentient, organic robot could indeed manifest all of these capacities. But such re-definitions do not resolve the genuinely interesting questions.

49. The typical labels used to classify views that minimize or deny a robust free will and related ideas include some varieties of materialism and physicalism, mechanism and random chance, and strong forms of naturalism. Consider, for example, claims of the following sort: "Every speech, thought, theory, poem, composition, and philosophy will turn out to be completely predictable in purely naturalistic terms. Some atoms-and-the-void account of microprocesses within individual human beings will permit the prediction of every sound or inscription which will ever be uttered." RICHARD RORTY, PHILOSOPHY AND THE MIRROR OF NATURE 387 (Princeton Univ. Press rev. ed. 1980); see also PETER ATKINS, ON BEING: A SCIENTIST's EXPLORATION OF THE GREAT QUESTIONS OF EXISTENCE, at xii n.1 (2011) ("I adopt the view that the whole of all there is can be accounted for in terms of matter and its interactions."); ROSENBERG, supra note 32, at 3; CHARLES TALIAFERRO, The Soul of the Matter, in THE SOUL HYPOTHESIS 26, 28 (Mark C. Baker \& Stewart Goetz eds., 2011) (quoting and critiquing Rorty). But cf. KEITH WARD, IN DEFENCE OF THE SOUL 163 (1998) ("If we come to see human being as machines for genes or assemblies of macro-molecules, then it becomes virtually impossible to see human existence as uniquely valuable or moral ideas as absolutely commanding or the rational pursuit of truth as more than ... illusion ...."); David Hodgson, Criminal Responsibility, Free Will, and Neuroscience, in DOWNWARD CAUSATION AND THE NeuROBюlogy Of FreE Will 227, 232 (Nancey Murphy et al. eds., 2009) ("Neuroscience approaches the brain as a kind of machine. . .."); James Lenman, Naturalism Without Tears, 22 RATIO 1 (2009) (arguing that expressive naturalism does not lead to a bleak nihilism); Heath White, Mattering and Mechanism: Must a Mechanistic Universe be Depressing?, 24 RATIO 326, 327-32 (2011); Andrew M. Bailey, Book Review, 120 MiND 534, 534 (2011) ("Materialism is widely taken as orthodoxy in the metaphysics and philosophy of mind."). For further discussion on how strict naturalism is incompatible with libertarian freedom, see generally CONTEMPORARY MATERIALISM: A READER (Paul K. Moser \& J.D. Trout eds., 1995); STEWART GOETZ \& CHARLES TALIAFERRO, NATURALISM 16 (2008), where the authors state that "[s]trict naturalism is incompatible with libertarian freedom"; DAVID Papineau, Philosophical Naturalism (1993); THE Waning of Materialism (Robert C. Koons \& George Bealer eds., 2010); and Stewart Goetz, Naturalism and Libertarian Agency, in NATURAlism: A CRITICAL ANALYSIS 156, 157 (William Lane Craig \& J.P. Moreland eds., 2000). 
widely and increasingly argued by scientists and philosophers that this would not be a bad thing overall. In fact, scientists and philosophers of the first rank have already begun to argue, as we shall see immediately below, that largely abandoning the idea of a robust free will, moral responsibility, and related ideas-especially in criminal justice and sentencing-might well be beneficial. Susan Blackmore, for merely one example, denies that there is a "real self" that is conscious, that constitutes one's identity, and that exercises free will in deliberation and choice. ${ }^{50}$ But Blackmore sees living one's life without reliance on this kind of inner self as both realistically possible and as involving "a kind of liberation." 51

There is certainly no reason to imagine that, if our culture were to largely abandon the idea of robust free will, the criminal justice and sentencing system would respond with massive socially-destructive increases in not-guilty judgments, trivial sentences for even the most obviously dangerous convicted defendants, or the mass release from prison of even the most continually violent offenders. ${ }^{52}$ To find a person, or a mere thing, to be unduly dangerous and without much future social or economic value is not to imply that the person or thing is at all free, morally responsible, or blameworthy. Nor should we expect such criminal justice and sentencing to embark upon waves of pointless, disutilitarian cruelty.

More positively, it has often been argued of late that minimizing the role of belief in free will-in general and in the criminal justice context in particular - will lead to constructive social progress and improved, more humane, sentencing and criminal justice institutions. ${ }^{53}$ The most commonly expressed idea along these lines is that

We must emphasize that it is technically possible to define any of the above terms so that they could be compatible with free will and moral or criminal responsibility. And, again, nearly every even hazily imaginable combination of positions has by now been actually endorsed in print.

50. Blackmore, supra note 43; see also Nigel Eastman \& Colin Campbell, Neuroscience and Legal Determination of Criminal Responsibility, 7 NATURE REVS. NEUROSCIENCE 311, 317 (2006) (arguing that the very idea of personhood is potentially jeopardized by increased biological insight and understanding).

51. Blackmore, supra note 43 .

52. See, e.g., Felipe De Brigard et al., Responsibility and the Brain Sciences, 12 ETHICAL THEORY \& MORAl PraC. 511, 521 (2009); Eddy Nahmias et al., Free Will, Moral Responsibility, and Mechanism: Experiments on Folk Intuitions, 31 MIDWEST STUD. PHIL. 214, 232 (2007).

53. See, e.g., Cashmore, supra note 33, at 4503-04; Luis E. Chiesa, Punishing Without Free Will, 2011 UTAH L. REV. 1404, 1454-57 (2011) (arguing for a more efficient and humane consequentialist approach to punishment without free will or blameworthiness); Gerald Harrison, Hooray! We're Not Morally Responsible!, 8 THINK 87, 94-95 (2009) (noting that humans, as determined "biological machines" or "big stupid clocks," should avoid radical unfairness to- 
doing away with free will and moral responsibility-thinking, as far as possible, might well lead to fewer emotionally overheated sentences and to less vengeful, vindictive, unenlightened, indignant, and excessive sentences and other criminal justice practices, ${ }^{54}$ perhaps even with a retained role for forgiveness. ${ }^{55}$ Free will-based punishments may commonly be thought of as being overly severe (in the sense of being harsh or less empathetic), being systemically naiive, and imposing more suffering than is likely required for optimal prevention and deterrence. ${ }^{56}$ The thought, overall, is thus: that a criminal justice system that relied as little as possible, or not at all, on free will would tend to be more broadly reasonable, more civilized, and more humane.

If these positive effects typically took place, they would generally be regarded as progressive. But it bears mentioning that, even if the effects took place as the reformers foresee, the broader public discourse would likely be affected in a less uniformly progressive way.

ward prisoners and should "make prisons much nicer" and more curative places without clarifying how it is possible to be unfair to a clock). See generally Nick Trakakis, Whither Morality in a Hard Determinist World, 19 SORITES 14 (2007) (discussing acceptance of hard determinism as potentially opening the door to reduced intemperate rage, less vengefulness, and expanded altruism, empathy, and concern for others).

54. See, e.g., Jonathan W. Schooler, What Science Tells Us About Free Will, in FreE WILL AND CONSCIOUSNESS: HoW MIGHT ThEY WORK 191, 200 (Roy F. Baumeister et al., eds., 2010). For a less optimistic, if not dystopian, possibility, consider the scenario posed by CzELAW MiLOSZ, THE CAPTIVE MIND 4 (Jane Zielonko trans., Mercury Books 1962) (1953) where he stated, “[a] man who used these pills changed completely. He became serene and happy. The problems he had struggled with until then suddenly appeared to be superficial and unimportant."

As a matter of terminology, we will assume that one can deny robust freedom of the will and still talk, in some mechanical sense, of giving payoffs and penalties, issuing rewards and punishments, giving reinforcers, signaling, incentivizing, nudging, steering, behavioral shaping, manipulating, coercing, constraining, controlling, and of giving mere social approval and disapproval, all of various strengths and directions. Our doubts will be reserved for those writers who continue to use all of the familiar terminology of moral responsibility, blameworthiness, etc. without clarifying that-on their own theories-only some limited, attenuated meaning of the latter terms is still available.

55. Schooler, supra note 55, at 200-01.

56. See id.; Kelly Burns \& Antoine Bechara, Decision Making and Free Will: A Neuroscience Perspective, 25 BEHAV. SCl. \& L. 263, 278 (2007) (describing neuroscience as undermining the legal conception of freedom of the will, but thereby opening the door to a more humane and effective criminal justice system); Ted Honderich, Effects, Determinism, Neither Compatibilism nor Incompatibilism, Consciousness, http://www.ucl.ac.uk/ uctytho/EffectsDetEtcConscK2

.html (last visited Sept. 3, 2012); see also TED HONDERICH, HOW FREE ARE YOU? THE DETERMINISM PROBLEM 141 ( $2 \mathrm{~d}$ ed. 2002) (suggesting a link between reduced reliance on free will and desert on the one hand and egalitarian or progressive politics on the other). Of course, if we are all essentially like complex scum or moulds, a certain kind of human equality is indeed thereby suggested, but not in a version that carries sufficient momentum toward a number of classic, progressive moral goals. 
As one philosopher observes, "[o]nce we reflect that all people, including those who hold abhorrent political views, are not morally responsible for being who they are, we can rid ourselves of the high-toned self-righteousness that poisons most political discussions." ${ }^{157}$ Thus, eradicating a belief in free will and moral responsibility should, in all logic, extend as fully to one's (previously) despised and detested political opponents - regardless of how egregious one views their conduct - as to those defendants one feels sympathy for as victims of an economic system or their impoverished environment. ${ }^{58}$

It is unclear whether those writers who have already abandoned belief in free will indeed invariably speak of those with whom they disagree with a tone and content consistent with their newly enlightened belief. If they have not invariably done so, that inconsistent behavior might well be strategically and rhetorically understandable. Anti-free will writers who are thereby logically barred from genuinely blaming their political and intellectual opponents might, under our current adversarial culture, ${ }^{59}$ often be at a distinct rhetorical disadvantage with respect to those who continue to think that indignantly blaming opponents for their freely made wicked choices is still sometimes appropriate. One might even wonder whether finding one's political opponents to be invariably blameless might eventually tend to sap one's motivation and fervor in promoting one's adopted causes.

In any event, the political effects of more or less abandoning free will and related ideas across the board may well vary, depending upon whether such a view is held at first only by a limited and dis-

57. Tamler Sommers, The Objective Attitude, 57 PHIL. Q. 321, 336 (2007). Query, though, whether abolishing righteous anger toward all criminal defendants might eventually tend to sap our motivation to appropriately deter or punish, at some real cost, war crimes or mass human rights violations at a presumably safe distance. For an optimistic view on this issue, see DERK PEREBOOM, LIVING WITHOUT FREE WILL 185-86 (2001).

58. See generally R. George Wright, The Progressive Logic of Criminal Responsibility and the Circumstances of the Most Deprived, 43 CATH. U. L. REV. 459 (1994) (discussing culpability of criminal defendants from unfortunate circumstances).

59. For a sense of the dynamics of increasingly extreme, and even agonistic, political and cultural rhetoric, see generally R. George Wright, Self-Censorship and the Constriction of Thought and Discussion Under Modern Communications Technologies, 25 NOTRE DAME J.L. ETHICS \& PUB. POL'Y 123 (2011). Note that, at some stages of the French Revolution, sheer ferocity in practice sometimes extended beyond what many of the opinion leaders might have preferred. See generally WILLIAM DOYLE, THE OXFORD HISTORY OF THE FRENCH REVOLUTION (2d ed. 2002). 
tinct group or by the broad public and by public officials generally. ${ }^{60}$ Even more importantly, the politics of abandoning free will and related ideas in the criminal justice and sentencing contexts will surely depend on what the public takes to be the available criminal law policy alternatives and their various respective tangible and intangible costs. Query, for example, how the public would react to cheaply and permanently assigning an apparently incorrigibly violent criminal to some sort of socially harmless virtual worldassuming, crucially, that no one is really invested with basic human dignity.

We can begin to develop an idea of what abolishing free will based policies might mean by considering some illustrative forms of serious criminal behavior, ${ }^{61}$ some data on criminal recidivism, addiction, and brain development, ${ }^{62}$ some direct and indirect costs of the current criminal justice system, ${ }^{63}$ along with some speculative sentencing alternatives that assume the non-existence of robust, meaningful, genuine free will and those notions dependent upon free will. ${ }^{64}$ We briefly explore these considerations below.

60. A similar point might be made, for example, about endorsing some forms of pacifism, adopting the vice of undue self-indulgence, or even embarking on a path of criminal violence as a lifestyle.

61. See infra Part III.

62. See infra Part III.

63. See infra Part III.

64. Given the costs, uncertainties, risks, murkiness, incompleteness, and even the incoherencies in adopting nearly any approach to free will and moral responsibility, it is not surprising that there has lately been some tendency to reverse the standard order of the inquiry. To thus decide whether persons really have free will based on raw pragmatism or on the assumed ethical and other consequences of so holding - as opposed to determining whether free will, however defined, really exists and only then, and on that basis, deciding the ethical and legal questions. We may call this reversal strategy a pragmatic approach, but we cannot assume that it offers a genuine net payoff. The first hurdle for such strategies is that they will inevitably seem intuitively backward, question-begging, arbitrary, and potentially open to finding free will and moral responsibility where they do not exist for the sake of some desired moral or other value. There may be no reason to conclude that a pragmatic strategy will actually lead pragmatically to desired long-term results. See DENNETT, supra note 41 , at 297-302 (2003); David A. Pizarro \& Eric G. Helzer, Stubborn Moralism and Freedom of the Will, in FREE WILL AND CONSCIOUSNESS, supra note 54, at 101-15. For further illumination, see E.P. EVANS, THE CRIMINAL PROSECUTION AND CAPITAL PUNishMENT OF ANIMALS (reprint ed. 2010) (1906). 


\section{SOME ILLUSTRATIVE FORMS OF SERIOUS CRIMES}

\section{A. The Particularly Horrific Crime Cases}

Kenneth Loggins, age seventeen and with no significant criminal history at the time of the offense in question, ${ }^{65}$ was initially sentenced to death and then to life without parole for murdering a female hitchhiker. ${ }^{66}$ The defendant's and his three colleagues' use of alcohol and drugs may have facilitated the murder. ${ }^{67}$ According to the Eleventh Circuit's account, Loggins and his colleagues lured the victim to a remote area, prevented her escape by hitting her on the head with a beer bottle, tackled her, repeatedly kicked and viciously beat her, and stood on her throat until death ensued. ${ }^{68}$ Post-mortem, the victim was transported, her clothes were removed, and her body was then elaborately defiled before being tossed over a cliff. ${ }^{69}$ The defendants made various efforts to conceal their involvement, about which they later joked. ${ }^{70}$

The nature of the defendant's treatment of the victim is suggested by the autopsy report, as summarized by the Eleventh Circuit, according to which:

[The victim's] face was covered with lacerations, every bone in her face was fractured at least once, almost every bone in her skull was fractured, a tooth was missing, her left eye was collapsed, her right eye had hemorrhaged, there were two large incisions in her chest, her left lung had been removed, she had 180 post-mortem stab wounds, and all of her fingers and both thumbs had been cut off. ${ }^{71}$

This brief account is not maximally graphic, but it is still likely to inspire emotional reactions. To some degree, those emotions may not entirely depend upon anyone accepting the supposed extravagances of free will, genuine moral responsibility, moral blameworthiness, and so forth. For the sake of argument, we shall simply assume that any and all negative emotions anyone might feel regard-

65. See Loggins v. State, 771 So. 2 d 1070, 1091 (Ala. Crim. App. 1999), aff d sub nom. Ex parte Loggins, 771 So. 2d 1093 (Ala. 2000).

66. See Loggins v. Thomas, 654 F.3d 1204, 1207 (11th Cir. 2011).

67. See id.

68. See id.

69. See id.

70. See id. at $1207-08$.

71. Id. One of the victim's fingers had been kept by one of the perpetrators in a zip-lock bag, leading, upon its display, to the arrest of the defendants. See id. 
ing Loggins can be entirely attributed to just such extravagances, and over time, such emotional reactions could fade once their mistaken presuppositions are exposed and rejected.

It might be tempting to then conclude that the defendant Loggins would then be treated with humaneness and a certain enlightened or, at least, disinterested consideration based on the presumed advances of scientific theory and practice. But, once familiar ideas such as the basic human dignity associated with free will and autonomous choice are, indeed, really presumed to have largely evaporated, the likely official disposition of Loggins is no longer so clear. As a matter of logic, neither more nor less than his victim or than any of his neighbors, Loggins may be considered, in the terms of some especially forthright observers, as a chemical scum, a slime mould, a sentient puppet, a complex, organic robot, or a memeinfested ape, according to one's preferred metaphorical view. ${ }^{72}$ Why a culture, a neighborhood, or a criminal justice system would then go out of its way, in some evidently non-utilitarian or socially costly and risky fashion on behalf of such an offender is then entirely unclear.

We have not yet cited much of the relevant contemporary neuroscience work, ${ }^{73}$ but it will plainly not be plausible, for example, to claim that Loggins's behavior is the sort of thing one simply might expect from an immature, seventeen-year-old male with stilldeveloping pre-frontal lobes ${ }^{74}$ and, thus, impaired judgment under the influence of drugs and alcohol. ${ }^{75}$ Most seventeen-year-old males manage to avoid such sustained horrific behavior.

Let us also accept that Loggins apparently had some skinhead associations ${ }^{76}$ and suffered rages ${ }^{77}$ that were perhaps entirely organically, chemically, or neurologically driven. We might then interpret such rages as not only mitigating culpability, but as adding perhaps a redundant layer to the complete exculpation from genuine responsibility already in place once we more broadly abandon moral re-

72. See supra Part I. Notice that, even at the initial trial stage, we are classically inclined to think that it is better for a dozen, guilty defendants go free than that a single, innocent defendant be convicted. Would we equally say this of complex, sentient, organic robots? Would it also be better to let loose a dozen, continuingly dangerous robots on the public than to confine a single, non-dangerous robot we falsely think to be dangerous?

73. See infra Part II.E.

74. See infra Part II.E.

75. See Loggins, 654 F.3d at 1207.

76. See id.

77. Loggins v. State, 771 So. 2d 1070, 1084-1106 (Ala. Crim. App. 1999). 
sponsibility in general. But the logic of and the motivation for humaneness in this and similar cases nevertheless remains murky.

By all means, if Loggins could somehow be inexpensively, humanely, assuredly, and permanently cured of his anti-social impulses, that course of action could certainly be widely popular and officially imposed with or without Loggins's (non-autonomous) consent. If, on the other hand, medicine and science could as yet not reliably guarantee any such inexpensive, humane, assured, permanent cure-and if we assume Loggins to be no freer, no more responsible, and no more invested with essential dignity than any of the rest of us complex, sentient, organic robots - it is entirely unclear why Loggins's neighbors, potential neighbors, or fellow taxpayers would want to spend remarkable and apparently disproportionate sums on his humane care and custody. Even if we are all deemed equally vaguely robotic, un-free, and non-responsible, we can still tell a distinct difference between Loggins and, say, the seventeen-year-old spelling bee entrant, $4-\mathrm{H}$ club member, choir singer, or future teacher.

This is, again, clearly not a matter of blaming Loggins. But it is also not difficult to imagine his neighbors thinking of Loggins, their fellow complex, sentient, organic robot who is equally devoid of fundamental personal dignity ${ }^{78}$ as still distinctive, in the sense of posing unusually severe risks and as being irreparably seriously "defective." Such defectiveness might again be a matter of biology, broader economic and social structures, or both. Loggins might be widely viewed as not repairable to any acceptable degree, as a substantial risk to many persons over time, and, frankly, as not worth substantial private or neighborhood risks, public expenditure, or social investment even in his own custodial arrangements. Loggins would be judged on some utilitarian or other consequentialist calculus, ${ }^{79}$ taking reasonable account of Loggins's own sentiments, the

78. For background discussion of dignity in the relevant sense, see generally R. George Wright, Consenting Adults: The Problem of Enhancing Human Dignity Non-Coercively, 75 B.U. L. REV. 1397 (1995); R. George Wright, The Death Penalty and the Way We Think Now, 33 LoY. L.A. L. REv. 533 (2000); R. George Wright, Treating Persons as Ends in Themselves: The Legal Implications of a Kantian Principle, 36 U. RICH. L. REV. 271 (2002); and the sources cited therein.

79. The idea of private or public decision making on a consequentialist, or any spare, vaguely utilitarian calculus refers to those considerations-including realistic fears and various costs - that could be taken into account when deciding how to address a more or less dangerous convicted defendant, ruling out all considerations, arguments, and emotions that depend upon abandoned ideas of a robust free will, moral responsibility, fundamental dignity, and autonomy. Otherwise, the term "utilitarianism" is not intended here in any restrictive sense. 
sentiments of his family and friends, and his likely net cultural value or productivity in the future-broadly understood. The case for prolonged and substantial public expenditures and public risks on Loggins's behalf may well strike many as utterly unpersuasive.

Reducing the classically human to the loosely robotic may thus, indeed, have practical implications and not all of them are likely to be socially or economically sacrificial and humane. We do not endlessly waste resources on what we regard as irreparably defective machinery, whatever the sophistication of that machinery. Instead, we normally apply some sort of broad cost-benefit analysis and move on. Humaneness may normally prohibit inflicting useless pain or discomfort on anyone, especially over time. But it is difficult to believe that this minimal requirement exhausts what we mean by humaneness.

\section{B. The Horrific Background and Horrific Crime Cases}

The case of Robert Alton Harris has been widely discussed. ${ }^{80}$ Most people would regard both Harris's crime, as well as his own background, as horrific. As to the former, consider merely an excerpt from a Ninth Circuit recitation:

Harris and the [two homicide victim] boys agreed that the boys [post-kidnapping and car theft] should walk to the top of a fire trail, wait until Harris and his brother had left, and

\footnotetext{
For some dimensions of the sheer openness and crucial indeterminacy of the idea of utilitarianism, see David Lyons, The Moral Opacity of Utilitarianism 10- 14 (Bos. Univ. Sch. of Law Pub. Law \& Legal Theory Working Paper Series, Paper No. 99-97, 1999), available at http:/ / papers.ssrn.com/paper.taf?abstract_id=212288. Although one leading scholar has estimated the value of a life in the United States, in some contexts, as ranging between four and ten million dollars, this figure may reflect our still common perception of the immense value of a free, autonomous, fundamentally dignified person and not exclusively the image or market value of a sentient, complex robot. See W. Kip Viscusi, The Value of Life 4 (Vanderbilt Univ. Law Sch. \& Econ., Working Paper No. 08-04, 2008), available at http://ssrn.com/ abstract $=827205$.

80. Harris v. Vasquez, 949 F.2d 1497 (9th Cir. 1990). Judge John Noonan, who wrote a separate opinion, later authored John T. Noonan, Jr., Horses of the Night: Harris v. Vasquez, 45 STAN. L. REV. 1011 (1993). For more on Harris, see Evan Caminker \& Erwin Chemerinsky, The Lawless Execution of Robert Alton Harris, 102 YALE L.J. 225, 225-54 (1992); Stephen Reinhardt, The Supreme Court, the Death Penalty, and the Harris Case, 102 YALE L.J. 205, 205-23 (1992); and Charles M. Sevilla \& Michael Laurence, Thoughts on the Cause of the Present Discontents: The Death Penalty Case of Robert Alton Harris, 40 UCLA L. REV. 345, 345-79 (1992). A discussion that most clearly illuminates both the horrific nature of Harris's crime and the horrific life and background Harris faced, prenatally and thereafter, is found in an essay written by Gary Watson, Responsibility and the Limits of Evil: Variations on a Strawsonian Theme, in RESPONSIBILITY, CHARACTER, AND THE EMOTIONS 256, 268-80 (Ferdinand Schoeman ed., 1987).
} 
then report the car stolen, giving misleading descriptions of the thieves. When the boys began walking up the hill, Harris shot [one boy] in the back. Harris fired another shot into [the first boy's] head, and then ran after [the second boy]. Finding [him] crouching and screaming in the brush, Harris shot him four times. Harris then returned and shot [the first boy] point-blank into his head. Finally, Harris took the rifle . . . and shot [the first boy] again. ${ }^{81}$

As the Ninth Circuit then reports, Harris and his accomplice brother then returned home and, in a peculiar detail that many persons find particularly telling, "Harris ate the remainder of the boys' hamburgers and laughed at [his brother] for not having the stomach to join him." ${ }^{82}$

It would be wrong, though, to conclude that Harris was incapable of imagining how other persons would feel and behave under any particular circumstances. As the two brothers continued to plan their bank robbery, carried out later in the day, "Harris laughed and giggled about shooting the boys, saying he had blown [the second boy's] arm off and amused himself by imagining what it would be like to be a police officer and report the deaths to the boys' families." ${ }^{83}$

This brief recounting gives some indication of the horrific quality of Harris's crime and his reaction thereto. But there is another side to Harris's story, which can as well be thought of as horrific in its own way. Harris was diagnosed with organic brain damage possibly caused by chronic glue and solvent sniffing. ${ }^{84}$ The latter behavior would presumably not be stigmatizing, regardless of its motivation, if we assume away free will and moral responsibility. We do not blame victims for the unavoidable effects of fetal alcohol syndrome from which Harris may have also suffered. ${ }^{85}$

Furthermore, testimony indicated that, post-natally, Harris suffered extreme abuse. ${ }^{86}$ According to the testimony of relatives, the husband of Harris's mother denied paternity for a number of years, showed Harris no affection, would not allow his wife to show Harris any affection, abused Harris's mother, knocked Harris out of his

\footnotetext{
81. Harris, 949 F.2d at 1501 .

82. Id.

83. Id.

84. Id. at 1502 .

85. See id. at $1506-07$.

86. Id. at 1505-06.
} 
high chair, tried to choke him with a tablecloth, beat him into unconsciousness, and was "eventually sent to prison for child abuse and molestation. ${ }^{187}$ Although these circumstances and others hardly allow us to predict the specific likelihood or severity of any future crime, Harris's future anti-social behavior, at a general level, can hardly come as a surprise.

In Harris's case, the expert witnesses were less than unanimous on how much explanatory weight should be attributed to "organic personality disorder" and how much to "antisocial personality disorder." ${ }^{88}$ Given the still widespread belief in free will, some people may be more inclined to blame someone for acting in accordance with an anti-social personality-however derived - than to blame someone whose behavior reflects some physical, organic, and clinically-observable brain abnormality. ${ }^{89}$ Whether this difference always makes sense, assuming that free will is somehow possible, may well be questionable.

But because we are assuming a universal lack of free will, behavior that is somehow irresistibly caused by an observable, organic malformation in the brain and behavior that merely reflects one's personality, antisocial or not, would, by most, be considered equally blameless. ${ }^{90}$ One very pragmatically relevant difference, certainly, is that, as medical science progresses, organic brain abnormalities and behavioral predispositions may be curable with very different degrees of effectiveness, permanently or temporarily, at very different social costs.

It is, more generally, hard to see why a potentially affected neighborhood, a broader public, or the criminal justice system - again, assuming that we are all something vaguely like sentient, organic robots - would not want to take into account the likeliest and most important risks, treatment limitations, and comparative costs into its sentencing, treatment, and other penological decision making. As merely one consideration, there was testimony in the Harris case

87. Id.

88. Id. at 1506-09.

89. Any such tendency might parallel the common inclination to deny or reduce criminal culpability in cases where the standard excusing or mitigating conditions - such as duress, coercion, or necessity - are thought to be (sufficiently) present, but not where an equally strong causal mechanism may well have been at work, leaving no visible track for scientists or juries to follow. See generally Nahmias et al., supra note 52.

90. If, let us say, all human behavior is determined or is partly random in ways not involving free will, then even the most overwhelming organic brain defect would, at most, constitute either a part of the pathway from the behavior itself back to its ultimate causes or some redundant, second-level determinant of the behavior - what we might call over-determination. 
that persons with antisocial personality disorder not only tend to be emotionally unstable, callous and irresponsible, ${ }^{91}$ but also that "they seem to have an inability to profit from past experience or punishment." ${ }^{\prime 2}$

If such persons really tend to gain little from these experiences and are assumed to lack free will, moral responsibility, the dignity of the person, and genuine personhood itself, then public policy could potentially still take any of several directions. We could, in theory, conclude that, if such persons are unlikely to meaningfully benefit from prison, they should instead be more or less released into the broader community. We could also hope that a cheap, highly effective, permanent cure will soon be developed and then applied to the offender with or without the offender's consent. Even if such a cure fundamentally altered the offender's personality, perhaps painlessly if not pleasurably, any harm in "repairing" a being analogous to a defective, organic robot-and without basic dignity or classical personhood -is entirely unclear at best.

Other options would include an expensive death penalty appeals process drawn out over decades or a remarkably expensive system of incarceration. However, the death penalty or incarceration are both available at a reduced cost and could be attractive in an era of less than continuously robust economic growth and long-term deficit prospects. It is certainly easy to imagine a community realistically concluding that, if a violence-prone prisoner is especially unlikely to profit from prison experience, ${ }^{93}$ that prisoner should not be released among the general population until the risk of serious harm to any innocent person is clearly and demonstrably below some low threshold level.

At no stage in this or any related consideration would the community or its representatives be committed to the idea that a prison-

91. See Harris, 949 F.2d at 1504.

92. See id. See also the testimony in the important juvenile murder defendant mitigating evidence case of Eddings v. Oklahoma, 455 U.S. 104, 107-08 (1982). In Eddings, an expert witness for the prosecution testified that "approximately $30 \%$ " of juveniles with "sociopathic or antisocial personality" outgrow that disorder as they age while a psychiatrist "testified that Eddings could be rehabilitated by intensive therapy over a fifteen-to-twenty-year period." Id. Such expert assurances may not be especially convincing to those citizens who might well have contact with such a person over the specified time frame or even to those citizens expected to bear the direct financial costs of fifteen to twenty years of intensive therapy.

93. Such a prisoner would, again, seem an appropriate prospect for any cheap computer technology that painlessly consigns the prisoner to harmlessness in some illusory but convincing virtual world; again, in principle, there would be no serious dignitary costs with which to contend. 
er is deeply "inferior" to anyone else, that some or all prisoners simply "do not count," or that some or all prisoners "deserve" to suffer useless pain. These attitudes would clearly be inconsistent with the assumptions we are at this point adopting.

In such prisoner cases, the public might also consider whether the convicted defendant possesses or is likely to acquire and utilize economically valued skills; is particularly beloved by a significant number of persons who value his immediate physical presence; or is likely to burden the community or any victim's relatives with various other kinds of costs, including fear, dread, anxiety, or the stirring of painful or repellant memories. ${ }^{94}$ These considerations would, again, not be matters of arbitrary vindictiveness.

The bottom line, however, is that, if we set aside - to the greatest extent possible $-\mathrm{a}$ belief in free will and those concepts depending on a belief in free will, there is no obvious reason to expect the public response to these sorts of offenders to be especially humane, generous, accommodating, or typically more forgiving.

\section{The Multiple Arrest, Multiple Conviction, and Recidivism Problem}

The phenomenon of multiple prior convictions and recidivism is a familiar one. Career criminal and "three strikes" sentencing enhancement cases are common..$^{95}$ As an extreme example, consider the career of Kenneth Allen McDuff. ${ }^{96}$ McDuff was convicted of capital murder, a conviction that he challenged in several venues. ${ }^{97}$ At trial, the State offered accomplice evidence that the defendant kidnapped the victim, repeatedly sexually assaulted, beat, and confined her in the trunk of a car. ${ }^{98}$ At the punishment phase, the State offered evidence of several other rapes and murders allegedly committed by McDuff. ${ }^{99}$

94. This assumes the absence of free will does not abolish our understanding that intangible and indirect costs can be as real as tangible or direct, easily quantifiable, budgetary costs. See infra Part III (discussing a variety of additional, tangible cost issues).

95. See, e.g., United States v. Keith, 638 F.3d 851, 852 (8th Cir. 2011); United States v. Paige, 634 F.3d 871, 872-73 (6th Cir. 2011); United States v. King, 627 F.3d 321, 322-24 (8th Cir. 2010); State v. Slaughter, 711 S.E.2d 651, 651-52 (Ga. 2011); State v. Hunter, 915 N.E.2d 292, 293-94, 298-300 (Ohio 2009); State v. Langstead, 228 P.3d 799, 802 (Wash. Ct. App. 2010).

96. McDuff v. Johnson, No. 98-51022, 1998 WL 857876 *1-4 (5th Cir. 1998) (per curiam); see also McDuff v. State, 939 S.W.2d 607, 610-11 (Tex. Crim. App. 1997).

97. See McDuff, 1998 WL 857876, at *1.

98. Id. at *2-3.

99. Id. at *3. 
For our purposes, though, the crucial point is that McDuff and his alleged propensity for violence ${ }^{100}$ had not managed to fly under the radar of the police and the criminal justice system and had not evaded any official notice or examination. The Fifth Circuit opinion instead reports that "the State presented evidence of McDuff's sixteen prior felony offenses." 101

It can be argued that the widespread belief in free will and moral responsibility explains why a legal culture runs the risk of, and actually incurs, such grievous, apparently futile, continual severe suffering and harm. But nothing in the ideas of free will and moral responsibility prohibit a government from sensibly holding McDuff appropriately morally responsible at any earlier point, thereby preventing the later criminal activities. Also, nothing in the rejection of free will, moral responsibility, the basic dignity of the person, or personhood itself rules out a much earlier, less passive, less diffident, more socially protective, and less costly judicial and penological response to any person who exhibits a strong and sustained tendency toward violent criminal acts.

While the criminal activity involved in the McDuff case was especially egregious, it is broadly true that many serious felonies are committed by persons, adolescent or adult, with substantial and sustained serious prior contact with the criminal justice system. ${ }^{102}$ In the case of many serious offenses, the criminal justice system may already have had at least one, if not a number of, prior opportunities to take meaningful, realistic, and low-cost steps to prevent, with varying degrees of certainty, the later serious offense. ${ }^{103}$ According to one study, "[a]pproximately $40 \%$ of felony defendants had previously been convicted of a felony[.] The majority of felony defendants had at least one prior arrest (77\%) and 69\% had

100. See id.

101. Id.; see also Atkins v. Virginia, 536 U.S. 304, 337, 339 (2002) (Scalia, J., dissenting) (noting trial testimony "about petitioner's sixteen prior felony convictions for robbery, attempted robbery, abduction, use of a firearm, and maiming"). The multiple prior offenses in Atkins are discussed in MichaEL S. GAZZANIGA, WHO'S IN CHARGE? FREE WILL AND THE SCIENCE OF THE BRAIN 191-93 (2011).

102. See, e.g., Eve Mulder et al., A Classification of Risk Factors in Serious Juvenile Offenders and the Relation Between Patterns of Risk Factors and Recidivism, 20 CRIM. BEHAV. \& MENTAL HEALTH 23, 24 (2010).

103. Among severe adolescent offenders, there are greater recidivism rates-approaching $50 \%$ - for those classified as psychopathic, as distinguished from anxious or impulsive. See generally Jeanette Taylor et al., Recidivism in Subgroups of Severe Male Juvenile Offenders, 15 PSYCHOL., CRIME \& L. 395, 403 (2009). 
multiple prior arrests." ${ }^{104}$ Of those arrested for either murder or robbery, the majority had at least one prior conviction, about $40 \%$ had multiple prior convictions, and about $40 \%$ had at least one prior felony conviction. ${ }^{105}$

Often, then, the criminal justice system has had prior opportunities to rationally and unsentimentally address the dangers and risks posed by a serious criminal offender. According to one study, of those charged with the crime of robbery, $11 \%$ had one prior conviction, $16 \%$ had two to four prior convictions, $16 \%$ had five to nine prior convictions, and $11 \%$ had a remarkable ten or more prior convictions. ${ }^{106}$ More than a third of those charged with robbery had ten or more prior arrests. ${ }^{107}$ At some point, a sustained official pattern of "catch and release" must itself be recognized as pathological in flouting the community interest. Overall, "the national recidivism rate has been largely stable, with roughly four in [ten] prisoners returning to prison within three years of release." 108 Of course, any number of factors can drive recidivism rates up or down. ${ }^{109}$

If we think of all such offenders or, at least, those beyond juvenile status as dignified and autonomous, yet often economically subordinated and poorly educated persons who could presumably reorder their values and priorities at any point, then many of us may not want to give them the benefit of any realistic and substantial doubt in sentencing. People with even structurally limited economic opportunity are not inflexibly programmed.

But if we think of multiple, perhaps sixteen-time felony recidivists instead as, like the rest of us, incapable of autonomy and without

104. Thomas H. Cohen \& Tracey Kyckelhahn, Felony Defendants in Large Urban Counties 2006, in BUREAU OF JUST. STAT., U.S. DEPT. OF JUST. 4 (May 2010), http:/ / bjs.ojp.usdoj.gov/ content/pub/pdf/fdluc06.pdf.

105. See id. at 5 , tbl.4.

106. See id. at 22, app. tbl.5.

107. See id. at 21, app. tbl.4. (listing the total number of robbery defendants in the sample as approximately 3,400); see also Mark A. Cohen et al., Studying the Costs of Crime Across Offender Trajectories, 9 CRIMINOLOGY \& PUB. POL'Y 279, 298 (2010).

108. The Pew Center on the States, State of Recidivism: The Revolving Door of AMERICA'S PRISONS 12 (2011), http:/ / www.pewtrusts.org/uploadedfiles/wwwpewtrustsorg/ Reports/sentencing_and_corrections/State_Recidivism_Revolving_Door_America_ Prisons\%20.pdf [hereinafter PEW CENTER].

109. See id. at 12,17-19 (" $[\mathrm{A}]$ state's recidivism rate is the product of numerous variables."). For a useful recidivism survey, see PATRICK A. LANGAN \& DAVID J. LEVIN, BUREAU OF JUSTICE STATISTICS SPECIAL REPORT: RECIDIVISM OF PRISONERS RELEASED IN 1994 1, 10-11 (2002). For a discussion of how neighborhoods impact youth recidivism rates, see Heidi E. Grunwald et al., Influences of Neighborhood Context, Individual History and Parenting Behavior on Recidivism Among Juvenile Offenders, 39 J. YOUTH \& ADOLESCENCE 1067, 1068-69 (2010). 
fundamental dignity, we may eventually be far less willing to react with grotesque shortsightedness, irrealism, passivity or sheer selfdestructive sentimentality. With reasonably cold neutrality and concern for the long-term interests and preferences of all, we would balance risks, probabilities, costs, and benefits as we then saw them without any sense of blaming. But we would also not blame wasps for objectively threatening a picnic. We would, collectively and unsentimentally, take reasonable and cost-effective steps to reduce the risks and harms posed by the morally blameless wasps. We would not likely imagine, after one or more wasp stings, that the blameless wasps should be presumed to be unlikely to sting again.

One would, of course, hope that any such comparison of human beings and mere wasps would be universally regarded as appalling, inappropriate, and degrading. Indeed, one would wish that the logic of the most vocal opponents of free will and dependent ideas could avoid all such implications. It is unclear why thinking of a human as a complex wasp is thought to be insulting, but thinking of that same human as anything remotely like a chemical scum, slime mould, meme-infested ape, sentient puppet, or complex, organic robot is not. ${ }^{110}$ We should not expect a complex wasp, if it is thought to pose a significant and likely threat, to be treated with socially costly or risky humaneness or with socially costly regard for an autonomy and fundamental dignity that even a highly complex wasp does not actually possess.

In principle, those who reject free will might argue that the risks and costs of recidivism are typically low or that experts can reliably sort out which offenders, whatever their status, are likely to commit additional serious crimes if given the opportunity. But to claim that recidivism rates are low -in the sense that convicted felons can, in general, be considered as not posing a distinctively serious risk of harm to their communities-seems extremely dubious in light of the above statistics. ${ }^{111}$ And the ability of even the experts to predict individual recidivism has not yet reached a level of accuracy sufficient to reasonably allay the concerns of vulnerable members of the community. ${ }^{112}$

110. See discussion supra Part I.

111. See supra notes 102-09 and accompanying text.

112. See, e.g., Mulder et al., supra note 102 , at 35 ("[W]e found a nine-factor solution that is useful in understanding recidivism in serious juvenile offenders, but one that must be treated with caution as the explained variance of the regression model is low."). 
A recently developed predictive model for recidivism among serious juvenile offenders, for example, considers various family background factors, peer group factors, and personal factors, and ultimately settles upon a model featuring no less than nine distinct factors. ${ }^{113}$ These factors include "anti-social behaviour during treatment, sexual problems, family problems, axis-1 psychopathology, offence characteristics, conscience and empathy, intellectual and social capacities, social network, and substance abuse."114 The authors candidly recognize the limited predictive power of even this sophisticated multi-factor model. ${ }^{115}$ This is hardly surprising, especially when we consider the sheer variety of, for example, arguably relevant "family problems." 116

Thus, even on the most rigidly deterministic and non-free willbased assumptions, the criminal justice system could hardly expect to combine increased humaneness with the ability to reliably assure a community that a serious offender, juvenile or otherwise, now poses no significantly enhanced serious risk to the community beyond that of a typical non-offender. Reduction of recidivism is always possible in various technological ways and at differing costs, but likely at the cost of what many of us would see as humaneness or the (formerly recognized) fundamental dignity of the offender. The affected community, assuming a disbelief in free will, moral responsibility, and any associated human dignity, would have no reason not to insist on the most coldly cost-effective judicial and penological response to serious threats as may become available. If this response turns out at some point to involve, say, involuntary but effective psychosurgery, ${ }^{117}$ for example, the arguments from basic dignity of the person and autonomy against such an illiberal travesty, as we now see it, would be unavailable.

113. Id. at $23-24$

114. Id.

115. See id. at 35.

116. Id. at 34 .

117. For a review of psychosurgical procedures, especially the prefrontal lobotomies once commonly practiced on involuntary patients with mental illness, see Robert P. Feldman \& James T. Goodrich, Psychosurgery: A Historical Overview, 48 NEUROSURGERY 647 (2001) and ELLiOT S. VALENSTEIN, GREAT AND DESPERATE CuRES: THE RISE AND DECLINE OF PSYCHOSURGERY AND OTHER RADICAL TREATMENTS FOR MENTAL ILLNESS (2010). 


\section{The Drug and Addiction Cases}

The relationships among illegal drug use, sale, addiction, decriminalization, taxation and actual tax collections, treatments, relapse, and crime are obviously complex. Our focus herein will suggest that the presumed evaporation of free will and moral responsibility cannot be assumed to lead to a more general public policy toward various drug-related offenses. Although no moral blame or other moral condemnation would attach to such offenses, the sensate, robotic offender would inescapably lack the fundamental human dignity of the person as well.

Drug-related violent crimes could, in a sense, be considered less socially threatening than other sorts of crimes, if such crimes happen to be less difficult to solve. Perhaps some addictive, drug-related violent crimes, even if planned, reflect desperation more than detailed foresight. ${ }^{118}$ But it is unclear that the most likely affected publics would reasonably favor leniency or fallible treatment programs not involving isolation or imprisonment in such cases.

It is also certainly possible that decriminalizing the possession or sale of particular drugs would lead to fewer related crimes. ${ }^{119}$ But decriminalization can be argued for just as readily on grounds either presupposing or not presupposing free will. Autonomy-based, or libertarian, arguments for decriminalization would actually seem more naturally at home on the assumption of the possibility of free will. ${ }^{120}$

The case for decriminalization may also vary in its persuasiveness depending upon the drug in question and upon the realistic effectiveness and costs of current or future medical or surgical treatments. Whatever the social costs of methamphetamine, ${ }^{121}$ for example, and whether decriminalized or not, the relevant communities

118. In State $v$. Landfair, the defendant was sentenced to life without parole as a fourth offender upon conviction of first degree robbery. 70 So. 3d 1061, 1063 (La. Ct. App. 2011). The defendant wore a mask to conceal his identity during a hotel safe robbery; but, when handed one set of keys, he demanded a different key that would allow him to access cash proceeds of the hotel's current shift, thereby suggesting, correctly, his status as a current or former employee. Id.

119. For background, see the arguments made in DOUGLAS HUSAK \& PETER DE MARNEFFE, THE LEGALIZATION OF DRUGS 66-71 (2005). It would perhaps be imprudent to imagine, though, that reducing the realistic price of a drug would leave the quantity of drug consumption unchanged or that the government could completely monopolize, standardize, or invariably tax drug sales.

120. See sources cited supra note 36 and accompanying text.

121. See Rachel Gonzales et al., The Methamphetamine Problem in the United States, 31 ANN. REV. Pub. HEAlTH 385, 386 (2010). 
could view current treatments and $50 \%$ relapse rates as respectively ineffective and, based on any utilitarian calculus, unacceptably high. ${ }^{122}$ On the other hand, if a cheap and highly effective medical or surgical technique to "cure" methamphetamine addicts were to become available, a public disabused of the ideas of free will and dignity might insist on its routine imposition, regardless of most side effects and with or without the consent of the offender. In such cases, any sensible cost-benefit analysis, free will and dignity aside, might require procedures currently regarded as painless but not especially humane. It is entirely possible that, from a perspective beyond freedom and dignity, the affected public, including local taxpayers, might come to regard some serious non-consensual and violent sexual offenses in a loosely similar way.

Here again, as with much criminality, one could certainly argue that the most cost-effective way to address crime caused by various systemic and structural inequalities is by abolishing those broad inequalities. To such an approach, we certainly raise no objection. But the superior cost-effectiveness of such an approach or its degree of public appeal post-dignity, especially in an era of budget constraints, can hardly be guaranteed.

Under standard assumptions of free will and responsibility, courts are now universally unwilling to criminalize the mere status or condition of being currently addicted to an illegal drug, regardless of how that addiction arose. ${ }^{123}$ But one must ask to what extent this rule is actually a reflection of, and dependent upon, the criminal justice system's traditional foundations in free will and the dignity of the person.

If we largely set aside free will and elemental dignity, what is the remaining strength of principled, universal prohibition against a crime of voluntary or even involuntary drug addiction itself? Suppose the culture determines that possession or use of some particular illegal drug-heroin, perhaps-is sufficiently harmful to self or

122. See Mary-Lynn Brecht et al., Two-Year Outcomes of Treatment for Methamphetamine Use, Supp. 3 J. PSYCHOACTIVE DRUGS 415, 415-16 (2006) (discussing non-pharmacological treatments). While the figures tend to vary with the kind of treatment (e.g., residential or outpatient; duration of treatment; and the time period post-treatment), studies have cited a $50 \%$ relapse rate within a year and a half. See id.; Mary-Lynn Brecht et al., Predictors of Relapse After Treatment for Methamphetamine Use, 32 J. PSYCHOACTIVE DRUGS 211, 216 (2000) (discussing a Los Angeles County interview study). Presumably, more effective relapse prevention techniques, of one sort or another, will be devised over time.

123. See, e.g., Robinson v. California, 370 U.S. 660, 666-68 (1962). Herein, we focus on illegal drugs and set aside the cases of addiction to drugs that were originally properly prescribed. 
to others as to generally merit some form of continuing criminalization. Among typical adult heroin addicts - those with the mere status or condition of currently being addicted to heroin - the condition itself typically reflects the addicted person's knowing possession and knowing consumption of heroin on one or more prior occasions. Is such a person typically less dangerous to self or others than someone who happens to be caught with unconsumed heroin in his or her possession?

In the typical such case, could a community not reasonably infer a likely prior criminal act of illegal drug possession, within the statute of limitations, from the otherwise unexplained fact of the current status of addiction? ${ }^{124}$ Let us bear in mind that, even in typical drug possession cases, the ownership and control of the drugs may be contested, and not all criminal convictions need depend upon catching a defendant in some overt act. A sufficiently incriminating and not otherwise explainable set of later circumstances may suffice. ${ }^{125}$

Thus, if we largely set aside free will and dignity in the relevant senses, there seems to be no principled, universally applicable, cogent reason not to infer a specific, recent criminal act from an adult's present addiction to a particular illegal drug-even if the latter is merely a status or condition. Nor is there any decisive reason for a community to typically assume that someone who is (merely) currently addicted to an illegal drug is less dangerous to the community than someone who has been videotaped in voluntary possession of the same illegal drug.

As we saw in the case of methamphetamine, a community concerned more with reasonable self-protection than with free will and dignity might well endorse certain kinds of advanced medical and surgical treatments, voluntarily or involuntarily imposed, in some such cases. But, as long as the best affordable drug treatment programs have less than reassuring relapse rates, "humaneness" in the community response may require a higher cost than the community is willing to pay - or the community could reframe the most relevant question as one of adopting a humane policy and humane concern for the populations the addicted person is most likely to directly and adversely affect.

124. In some cases, the jurisdiction in which the possession offense occurred and, certainly, the quantities involved will be unclear.

125. Presumably, a human body evidently shot by someone and located in the fresh cement of one's basement floor could, with a showing of motive and opportunity, support an accusation of murder or some other "backward-looking" and not merely "present" offense, as in the case of (current) drug possession. 
More subversively, consider that the criminal justice system may look to present circumstances to establish a likely earlier crime. Might not the same system, casting free will and dignity aside, look to past and present circumstances and, in some cases, determine that the relevant utilitarian interests actually justify preventively restraining, detaining, or preemptively "treating" a person who is, on the basis of sufficient theory and evidence, considered a sufficiently likely and serious threat to community safety? ${ }^{126}$

Punishment-even for what is thought to be a person's sufficiently likely future, as yet uncommitted, crimes - would today, in most cases, reflect an overestimation of what the relevant science can show. But abandoning a belief in free will and the essential dignity of the person-including the ability to override even torrent-like causal streams - opens the door to a community's acting, however inhumanely in our own judgment, on the basis of advances in science and medical diagnostics ${ }^{127}$ and on the community's judgment of the threat posed by any given person, taking that person's likely economic and other contributions to the community into account. ${ }^{128}$

At this point, it should go without saying that, in reflecting on what communities might eventually be willing to do or to politically insist on in the absence of a constraining sense of free will and the dignity of the person, we are not herein at all endorsing any such community judgments. The moral unattractiveness of many such judgments is, instead, precisely our main point. And, as attractive as we now find attacking the economic and other structural causes of much crime, there is certainly no guarantee, now or in the future -

126. See generally United States v. Salerno, 481 U.S. 739 (1987); Paul H. Robinson, Commentary, Punishing Dangerousness: Cloaking Preventive Detention as Criminal Justice, 114 HARV. L. REV. 1429 (2001); Christopher Slobogin, A Jurisprudence of Dangerousness, 98 NW. U. L. REV. 1 (2003).

127. It seems possible that science and medicine could have good grounds for predicting likely future violence or other criminal activity on the part of a given person, without also being able to treat that person in such a way as to substantially reduce such risks to within acceptable limits.

128. For a contemporary debate over whether compatibilists - who, again, roughly seek to somehow coherently combine beliefs in some forms of both free will and determinism - can resist currently morally unattractive forms of pre-punishment, see, for example, Stephen Kearns, Compatibilism Can Resist Prepunishment: A Reply to Smilansky, 68 ANALYSIS 250, 250-53 (2008); Saul Smilansky, Determinism and Prepunishment, 67 ANALYSIS 347, 347-48 (2007); and Saul Smilansky, Prepunishment for Compatibilists: A Reply to Kearns, 68 ANALYSIS 254, 254-57 (2008). For a loosely related critique of Smilansky, see Neil Levy, Skepticism and Sanction: The Benefits of Rejecting Moral Responsibility, 31 L. \& PHIL. (forthcoming 2012), available at http://www.springerlink.com/content/e883644×25756272/. For a mere start on the complications of compatibilism in general, see discussion supra note 30 . 
especially given budget constraints - that a public that has set aside free will and responsibility will find what we would consider humane to be the most cost-effective or utility-maximizing approach to such crimes.

\section{E. The Non-Fully-Developed Adolescent Brain Cases}

In the case of State $v$. Ninham, the murder defendant Ninham was fourteen years old at the time of the alleged offense, and claimed he had suffered from abuse and alcohol dependency. ${ }^{129}$ The defendant was convicted and sentenced to life without parole. ${ }^{130}$ Of special interest for our purposes is the defendant's argument, with the aim of justifying a sentence modification, that the brain at age fourteen is still developing-particularly in the prefrontal cortex-such that "making impulsive decisions and engaging in risky behavior is an inevitable part of adolescence." ${ }^{131}$ This observation was then combined with the further argument that, "as the brain matures, adolescents almost universally grow out of their impulsive and risky behavior." 132 The defendant argued, finally, that "alcohol causes more damage to developing teenage brains than previously thought." ${ }^{133}$

Of course, there is no guarantee, in advance of well-interpreted empirical evidence and an understanding of causal mechanisms, that all three above elements of the defendant's sentencing modification argument will work together smoothly. At best, alcohol use by a teenager with a still-developing prefrontal cortex multiplies the risk of engaging in impulsive, ill-judged, or risky behavior during adolescence. But at worst, from the defendant's standpoint, is the possibility that some degree of presumably illegal alcohol use by

129. 797 N.W.2d 451, 474 (Wis. 2011).

130. Id. at 475 .

131. Id.; see also B.J. Casey et al., The Adolescent Brain, 1124 ANNALS N.Y. ACAD. SCI. 111, 111-12 (2008) (detailing the prevalence of risky behaviors in adolescence and advancing possible explanations).

132. Ninham, 797 N.W.2d at 475.

133. Id. This argument raises a much broader concern that not everything that the law takes to be a mitigating factor will be uniformly treated by even the most conscientious sentencing jury. A mitigating factor that strikes some jurors, even subconsciously, as indicative of continuing dangerousness may be treated as, in effect, a free-floating aggravating factor or else grossly discounted by a sentencing jury. The law's mitigator can be the affected neighbor's aggravator. If anything, this tendency would be enhanced among post-free will juries. 
teenagers could delay the process of brain maturation or the process of outgrowing immature behavior. ${ }^{134}$

In the absence of any belief in free will or the associated fundamental dignity of the person, there seems to be no reason why scientific uncertainties should generally be resolved against a community's desire to reduce obvious risks to its physical security and in favor of the liberty of, and disproportionate benevolence toward, the violent adolescent offender. Thus, adopting a uniform rule of resolving uncertainties in favor of the violent adolescent offender may well and sensibly strike the community as unwarranted.

Consider, for example, the allegations in the Ninham case itself. It is hardly clear that the charged conduct fits within what we would think of as adolescent, impulsive, ill-considered, risky, or even irresponsible behavior. As recounted by the Wisconsin Supreme Court, the victim was a thirteen-year-old, unknown to the five juveniles who set upon him without grounds or provocation. ${ }^{135}$

To condense the court's account, the defendants repeatedly punched the victim and eventually chased him to the fifth or top floor of a hospital parking garage. ${ }^{136}$ At that point, the defendant held the victim by his wrists while another assailant held the victim by his ankles with the two then swinging the victim back and forth out over the concrete wall of the top level of the parking ty. ${ }^{137}$ As the victim was being swung out beyond the wall, the two assailants released the victim's ankles and wrists, and the victim fell forty-five feet to the pavement below. ${ }^{138}$ The defendant was eventually brought to police attention by two of the initial five juveniles. ${ }^{139}$

Ninham received the maximum penalty permitted under the circumstances. ${ }^{140}$ But if we take the defendant to be, like all of us, essentially a complex, sentient, organic robot-only, in this case, with defective, dangerous, and perhaps even irreparable programming -

134. For a sense of some basic uncertainties regarding alcohol use, the developing adolescent brain, and behavior, see generally Duncan B. Clark et al., Alcohol, Psychological Dysregulation and Adolescent Brain Development, 32 AlCOHOLISM: CliniCAL \& EXPERIMENTAL Res. 375 (2008).

135. Ninham, 797 N.W.2d at 457.

136. Id.

137. Id.

138. Id.

139. Id. at 458 .

140. Id. at 459-60, 478. See the limitations imposed by cases such as Roper $v$. Simmons, 543 U.S. 551, 569 (2005) and Graham v. Florida, 130 S. Ct. 2011, 2030 (2010). 
whatever the ultimate causes of such circumstances, then new vistas of societal response inevitably open up. Unless we have sound reason to believe the defendant to be cheaply "repairable" in a reasonable time period and likely a distinctly productive, contributing member of society as an adult, why would the society choose to lavish significant resources on this defendant, including expensive treatment, particular amenities of incarceration, training for jobs in likely short supply, or even, beyond a certain point, continued appellate litigation?

In other words, if we are to go beyond free will and dignity, ${ }^{141}$ why not ask, most immediately, whether the defendant is likely to be worth the risks and costs based on whatever standards the public cares to adopt? The defendant's own wishes and interests or, at least, pains and pleasures could certainly be factored into the public decision, ${ }^{142}$ but with only such weight as the community cared, within its vaguely utilitarian calculus, to bestow. ${ }^{143}$ Given the avail-

141. For one critical response to the idea of dignity in several but not all possible senses of the term, see Steven Pinker, The Stupidity of Dignity, THE NEW REPUBLIC (May 28, 2008), http:/ / pinker.wjh.harvard.edu/articles/media/The\%20Stupidity\%20of\%20Dignity.htm.

142. Cf. Joshua Greene \& Jonathan Cohen, For the Law, Neuroscience Changes Nothing and Everything, 359 PHIL. TRANSACTIONS ROYAL SOC'Y LONDON B 1775, 1783 (2004) ("[T]he consequentialist approach does not require a belief in free will at all. As consequentialists, we can hold people responsible for crimes simply because doing so has, on balance, beneficial effects through deterrence, containment, etc.").

Query, as a standard response, whether we could hold someone criminally responsible for an outcome in which she played no role, if it happens to be the case that doing so would, in fact, best promote deterrence, containment, social utility, or the overall best consequences. For that matter, why not simply judicially determine "up" to be "down," in a particular case, if that result would promote the best consequences?

The problem is, in part, that, unless we abandon the standard idea of moral responsibility or alter the idea beyond recognition, moral responsibility involves some limits on its application beyond generating preferred consequences. A falling rock or a complex mechanism cannot be morally responsible because of its very nature, regardless of any conceivable pragmatic payoff or collective convenience in holding to the contrary.

143. See id. at 1783-84. The overall utility of, say, weight-lifting equipment for those convicted of robbery or home burglary might no longer be clear. For a useful typology of the challenges or threats to some traditional ways of thinking that current or future developments in neuroscience might pose, see Michael S. Moore, Responsible Choices, Desert-Based Legal Institutions, and the Challenges of Contemporary Neuroscience, 29 SOC. PHIL. \& POL'Y 223 (2012), where Moore discusses eliminatist, determinist, epiphenomenalist, and fallibist challenges from neuroscience. For additional diverse, neuroscience-based perspectives, see, for example, in nonjudgmental alphabetical order, DEBORAH W: DENNO, BIOLOGY AND VIOLENCE: FROM BIRTH TO ADULTHOOD 126 (2007) ("If in fact only a small portion of our behavior will ever be open to explanation, it may be that each person's thoughts and movements are so thoroughly individualistic that they are impossible to predict ... . Until more information on human nature becomes available, the notion of complete freedom from responsibility is best left to utopian ideas ...."); Eyal Aharoni et al., Can Neurological Evidence Help Courts Assess Criminal Responsibil- 


\section{able policy alternatives, it is far from clear why anything like the physicalization, naturalization, or mechanization of the human}

ity? Lessons from Law and Neuroscience, 1124 ANNALS N.Y. ACAD. SCl. 145, 145 (2008) ("[T]he worth of neuroscience in criminal decisions is far from obvious, in part because there is not, and will never be, a brain correlate of responsibility."); David Eagleman, The Brain on Trial, THE ATLANTIC, http://www.theatlantic.com/magazine/print/2011/07/the-brain-ontrial/8520 (last visited Oct. 15, 2012) (“[W]e can build a legal system more deeply informed by science, in which we will continue to take criminals off the streets, but we will customize sentencing, leverage new opportunities for rehabilitation, and structure better incentives for good behavior."); Eastman \& Campbell, supra note 50, at 317 ("[S]ome might say that, were we to achieve [a high] level of biological understanding of ourselves, we would have 'biologically explained away personhood, and have subsumed both legal and moral responsibility into biology."); Grant Gillett \& Sam C. Liu, Free Will and Necker's Cube: Reason, Language and TopDown Control in Cognitive Neuroscience, 87 PHIL. 29, 41 (2012) (attributing great importance to the evidence for "'top-down' self-control" in some decisions); Dean Mobbs et al., Law, Responsibility, and the Brain, 5 PLOS BIOLOGY 693, 693 (2007) ("[M]any contemporary neuroscientists assume ... that violence and antisocial behaviour emanate from a mechanistically determined brain."); Stephen J. Morse, Genetics and Criminal Responsibility, 15 TRENDS COGNITIVE SCI. 378, 379 (2011), available at http:/ / repository.upenn.edu/cgi/viewcontent.cgi?article $=1088$

\&context=neuroethics_pubs ("We are reasonably confident that having a genetically induced MAO-A deficiency in interaction with childhood abuse causally increases the risk of criminal and antisocial behavior more than nine-fold. Nonetheless, there is no reason to believe that offenders exposed to that interaction did not act or form the required mental states."); David Pizarro, Why Neuroscience Does Not Pose a Threat to Moral Responsibility, 2 AM. J. BIOETHICS NEUROSCIENCE 161 (2011) ("[T]he mechanisms that give rise to our basic moral intuitions (such as that we should hold people responsible) are too deeply entrenched in the mind for us to abandon in any meaningful way - even if we had good reason to do so.") (echoing the conclusion of the philosopher P.F. Strawson, but perhaps underestimating the ability of our thinking to gradually change over time as in the cases of various sexual crimes and of historic and apparently deeply engrained biases against particular groups, particularly where it might benefit one's own group if one's thinking were to be revised); Russell A. Poldrack, Neuroimaging: Separating the Promise from the Pipe Dreams, THE DANA FOUNDATION (May 27, 2009), http://www.dana.org/news/cerebrum/detail.aspx?id=22220 (" $[\mathrm{I}] \mathrm{t}$ is impossible to say whether increased or decreased activity in a particular brain region is 'better' or 'abnormal' ... we cannot assume that individual brain areas are uniquely responsible for specific mental functions, and thus that activation of those regions tells us what a person is thinking."); Adina Roskies, How Is Neuroscience Likely to Impact the Law in the Long Run?, in A JUDGE's GUIDE TO NEUROSCIENCE: A CONCISE INTRODUCTION 66, 70 (Andrew S. Mansfield ed., 2010) ("[T]he law relies heavily upon folk notions. If the folk notions change dramatically, the law will likely follow suit. ... [I]t is by putting pressure on our intuitive notions of responsibility and agency that neuroscience may have the most far-reaching consequence for the law."); Adina Roskies, Neuroscientific Challenges to Free Will and Responsibility, 10 TRENDS COGNITIVE SCI. 419, 419 (2006); Maureen Sie \& Arno Wouters, The BCN Challenge to Compatibilist Free Will and Personal Responsibility, 3 Neuroethics 121, 121-22 (2010); and Maureen Sie \& Arno Wouters, The Real Challenge to Free Will and Responsibility, 12 TRENDS COGNITIVE SCI. 3, 3 (2008) ("[M]ore often than not, we act in an automatic and unaware fashion, making up reasons only as we go along. ... The reasons we come up with to justify [moral judgments] are post-hoc rationalizations that played no part in their generation."). For an early judicial case involving a claim of possible deficiency of enzymatic activity for monoamine oxidase $\mathrm{A}$ as a possible genetic basis for violent behavior, see Mobley v. State, 455 S.E.2d 61, 65-66, 65 n.2 (Ga. 1995). For useful discussion of the Mobley case, see Deborah W. Denno, Legal Implications of Genetics and Crime Research, 1995 GENETICS CRIM. \& ANTISOCIAL BEHAV. 248, 251-52 (1996). 
should typically result in a more humane response to plainly expensive offenders. ${ }^{144}$ Among the formerly dystopian possibilities, why not a cheap, permanent, and pleasant social sedation for the offender given advances in pharmacology, brain implants, or surgery? Such a course, in the absence of free will and the dignity of the person, may be thought more appealing and more cost-effective than a focus on patient autonomy or on an otherwise morally imperative redistribution of social opportunities and other structural reforms.

\section{SOME CURRENT COSTS: OF CRIME, OF IMPRISONMENT, OF LIFE SENTENCES, AND OF THE DEATH PENALTY}

If we largely set aside the standard conceptions of free will and the notions dependent upon them, it is not clear how much genuine justice will exist to which the resulting criminal justice system can aspire. But, at the very least, the idea of justice can be redefined so as to apply coherently even to complex, sentient, organic robots. Even complex, organic robots may, in some sense, prefer one state of affairs to another. Although there can be no fundamental dignitary costs in a society without dignity in the relevant sense, other kinds of costs - with less metaphysical baggage - may still be considered, to one degree or another. ${ }^{145}$ Certainly, the general ideas of tangible

144. It should be pointed out that any casual assumption that the post-Enlightenment rise of science and immense economic wealth has led to more humane prison systems, in comparison to an assumedly barbaric medieval system, is overstated. See G. GELTNER, THE MEDIEVAL PRISON: A SOCIAL HISTORY 102 (Princeton Univ. Press 2008) (addressing medieval prison conditions, including the scarcity of inmate violence against personnel; relatively low death rates from any cause; and, most strikingly, inmate access to the city and the outside world); KARL SHOEMAKER, SANCTUARY AND CRIME IN THE MIDDLE AGES, 400-1500 ix (2011) ("In its medieval form, sanctuary law granted a wrongdoer who fled to the church protection from forcible removal, as well as immunity from corporal or capital punishment. The fugitive might be required to pay a fine, forfeit his goods, perform penance, or go into exile, but almost without exception his body and his life were to be preserved. Laws carving out sanctuary protections appear in every medieval legal tradition.") (referring to the doctrine of St. Augustine on these matters); Celia Chazelle, Crime and Punishment: Penalizing Without Prisons, in WHY THE MIDDLE AGES MATTER: MEdieVAl LiGHT ON MODERN INJUSTICE 15, 16 (Celia Chazelle et al. eds., 2012) (providing a more nuanced view of medieval practices and explaining that "[d]espite all our lip service to rehabilitation as a penal goal, early medieval people were more concerned than we are about reintegrating wrongdoers into society."). It bears noting that writers such as Origen, Augustine, Bernard of Clairvaux, and Aquinas helped articulate the idea of the freedom of the will. See generally supra note 5 and accompanying text.

145. We should note that any sort of irrational or selfish group biases, preferences, and prejudices that logically depend upon free will or moral blaming would thus be ruled out. Unfortunately, many manifestations of such group biases, subtle or crude, do not seem to depend on the notion that the disfavored group has a freely willed choice in the matter. The disfavored out-group may be thought of as inferior for a wide variety of reasons without assum- 
and intangible costs, direct and indirect costs, narrowly focused and widely spread costs, monetary costs, psychological costs, short-term costs, and long-term costs would all remain viable.

For the moment, the costs of crime and the criminal justice system in our society remain, in various respects, truly remarkable in their sheer magnitude. The costs of crime are borne (at least initially) by victims; by reasonably fearful potential victims; by offenders; by neighborhoods, communities, and small businesses; by consumers; by taxpayers of all sorts; and by the wider society. ${ }^{146}$ These costs include, among other elements, the expenses of investigating, adjudicating, and treating or incarcerating suspects and convicts; ${ }^{147}$ psychological costs of past crimes and the specific or diffuse fear of future crimes; ${ }^{148}$ negative externalities and neighborhood effects; quality of life concerns; as well as the often undercounted and otherwise unnecessary range of expenditures in time, money, and lifechoices made by (among other entities) individuals, families, schools, airports, computer systems operators, retail stores, businesses, communities, and government entities seeking to avoid, displace, deter, insure against, or reduce the risks of a vast range of crimes. ${ }^{149}$

ing its genuine blameworthiness. There are simply some brute, or socially constructed, group preferences in favor of the groups with which each person happens to identify. Not even evolutionary survival value requires that we treat distant strangers, particularly those who will not be born for a decade or two, with the same regard as we treat our nearby contemporaries, potential rescuers, or trading partners. For a contrasting perspective, see generally EVOLUTION AND ETHICS: HuMAN MORALITY IN BIOLOGICAL AND RELIGIOUS PERSPECTIVE (Philip Clayton \& Jeffrey Schloss eds., 2004). Recall the sheer, multi-faceted openness and indeterminacy of the generic utilitarianism. See Lyons, supra note 79, at 6-14.

146. See, e.g., Paul Heaton, Hidden in Plain Sight: What Cost-of-Crime Research Can Tell Us About Investing in Police 2 (2010), http:/ / www.rand.org/content/ dam/rand/pubs / occasional_papers/2010/RAND_OP279.pdf.

147. See id.

148. See id. The harm thought of as psychological harm may depend, at least in part, on the idea of basic equal human dignity. This cost would not be imposed or felt in a culture that had abandoned that idea. But, on the other hand, that reduced cost could well be offset, several times over, by reduced expenditures that are now justified only by their role in preserving the ultimate human dignity of suspects and offenders. See Paul Dolan \& Tessa Peasgood, Estimating the Economic and Social Costs of the Fear of Crime, 47 BRIT. J. CRIMINOLOGY 121, 121-24 (2007); Paul Dolan et al., Estimating the Intangible Victim Costs of Violent Crime, 45 BRIT. J. CRIMINOLOGY 958, 958-59 (2005).

149. See Ezra Klein, Do We Underestimate the Cost of Crime?, WaSH. POST, July 11, 2011, http://www.washingtonpost.com/blogs/ezra-klein/post/do-we-underestimate-the-cost-ofcrime/2011/07/06/gIQAPYSl8H_blog.html (interviewing noted baseball numbers analyst Bill James). Note, in particular, the difficulty of calculating a dollar cost of (increased) anxiety or of reduced community morale and free interaction, as well as the costs of either otherwise undesired moving or otherwise undesired immobility. By the way of a very loose analogy, 
To the extent that some of the costs associated with crime have been estimated, the numbers arrived at sometimes exclude one or more of the above considerations or may focus solely on the costs of judicial trials, appeals, incarceration, and the operation of the death penalty system. It has been suggested that the costs of crime in developed countries might be $10 \%$ of GDP, with such costs in the United States amounting to perhaps one to two trillion dollars annually. ${ }^{150}$ The 18,000 U.S. homicides in 2007 might, in some sense, have cost "roughly $\$ 300$ billion." 151 The actual costs of crime-apart from any direct reference to the costs of trials, appeals, or any broadly punitive or other official response-are perhaps best described as substantial, pervasive, and only rarely reflected upon comprehensively.

Proposals to largely abandon judicial recourse to free will and related ideas may rightly point not only to ineffective current penology, but to our remarkable expenditures on criminal trials, appeals particularly death penalty appeals-imprisonment, and the many costs of the death penalty system. Again, here, arriving at any particular cost number involves some imprecision. But the general magnitudes involved are striking. A Pew Center on the States report, for example, indicates that annual "[t]otal state spending on corrections is now about $\$ 52$ billion, the bulk of which is spent on prisons. State spending on corrections quadrupled during the past two decades, making it the second fastest growing area of state budgets, trailing only Medicaid." ${ }^{152}$ The Pew Center report cited $\$ 78.95$ as the average daily cost of imprisonment for a typical prisoner. ${ }^{153}$ At the federal level, the annual cost of imprisoning the aver-

consider the real costs of the apparently thousands of emergency room visits attributable to rigid plastic "clamshell" packaging as an anti-shoplifting device. See Margaret Webb Pressler, Do Not Pry Open Until Christmas, WASH. POST (Nov. 30, 2006), http:/ /www.washingtonpost. com/wp-dyn/content/article/2006/11/29/AR2006112901575.html.

150. Jens Ludwig, The Costs of Crime, 9 CRIMINOLOGY \& PuB. POL'Y 307, 310 (2010). Again, much of what we think of as costs of crime or individual-level criminal behavior might quite sensibly be thought of as a cost of various structural barriers and inequities.

151. See Charles M. Blow, Op-Ed., High Cost of Crime, N.Y. TIMES, Oct. 9, 2010, at A21, available at http://www.nytimes.com/2010/10/09/opinion/09blow.html; see also Matt DeLisi et al., Murder by Numbers: Monetary Costs Imposed by a Sample of Homicide Offenders, 21 J. FORENSIC PSYCHIATRY \& PSYCHOL. 501, 506 (2010) (finding that a single murder results in more than seven million dollars in victim costs, justice costs, and lost productivity).

152. PEW CENTER, supra note 108 , at 1.

153. See id. at 6 . A somewhat lower, but still substantial, annualized figure of $\$ 24,000$ per prisoner has also been cited. See Lisa Lambert, States Seek to Escape Rising Prison Costs (May 20, 2011, 11:30 AM), http://www.reuters.com/article/2011/05/20/us-usa-statesprisons-idUSTRE74J3S920110520. 
age person was calculated as $\$ 28,284.16$ or $\$ 77.49$ on a daily basis while the costs of probation, parole, and supervised release are substantially lower. ${ }^{154}$ These figures involve an incarceration level of 2.3 million persons as of 2008, a strikingly high number in absolute terms, as a percentage of population or when viewed as an increase over the past several decades. ${ }^{155}$

Under our current practices, the threat of the death penalty, along with the costs of trying death penalty cases, death penalty appeals, and imprisonment prior to any execution, makes the broader death penalty system exceptionally costly in narrow budgetary terms. ${ }^{156}$ For the state of California in particular, it is claimed that "each of the [thirteen] prisoners executed in the state over the past three decades has cost more than $\$ 300 \mathrm{~m}$ [illion], ${ }^{\prime 157}$ with death row inmates in California costing an average of perhaps $\$ 90,000$ more than other prison inmates on an annual basis. ${ }^{158}$ These costs, in part, reflect the remarkably protracted length of stays on death row, rising nationally to an average of twelve years in 2008-and to nearly twenty years in California-with some waits on death row lasting more than twenty-five years. ${ }^{159}$

How might this picture change, if at all, if the legal culture were to abolish the familiar general ideas of free will and moral responsibility? We can easily imagine cost savings if offenders commonly could be cured of any significant tendency toward serious crime by some inexpensive surgical or other medical or therapeutic drug intervention. But, for the moment, no such therapy seems commonly available-at least none that those who would abolish free

154. See Newly Available: Costs of Incarceration and Supervision in FY 2010, UNITED STATES COURTS (June 23, 2011), http://www.uscourts.gov/News/NewsView/11-06-23/Newly_

Available_Costs_of_Incarceration_and_Supervision_in_FY_2010.aspx.

155. See JOHN SCHMITT ET AL., THE High BudGETARY COST OF INCARCERATION 1 (June 2010), http://www.cepr.net/documents/publications/incarceration-2010-06.pdf.

156. See, e.g., Richard C. Dieter, What Politicians Don't Say About the High Costs of the Death Penalty, FEMINISM \& NONVIOLENT STUD. ASS'N, http://www.fnsa.org/v1n1/dieter1.html (last visited Oct. 15, 2012).

157. Ed Pilkington, Death Penalty Costs California More than $\$ 300 \mathrm{~m}$ per Execution, THE GUARDIAN (June 20, 2011), http://www.guardian.co.uk/world/2011/jun/20/californiadeath-penalty-execution-costs (citing an average of $\$ 100,000$ annually in extra security, $\$ 1,000,000$ in extra trial costs, and $\$ 300,000$ for attorneys' fees for each appeal).

158. Kevin Johnson, Prisoners' Time on Death Row Doubles, USA TODAY (July 23, 2008, 11:26 PM), http://www.usatoday.com/news/nation/2008-07-23-Death-row-time_N.htm.

159. See id.; Arthur L. Alarcon \& Paula M. Mitchell, Executing the Will of the Voters?: A Roadmap to Mend or End the California Legislature's Multi-Billion Dollar Death Penalty Debacle, 44 LoY. L.A. L. REv. S41, S51 (2011) (citing a cost of $\$ 4$ billion for the California death penalty system since 1978) 
will and moral responsibility would consider "humane." And, if there were such miracle cures, it is unclear whether most exponents of free will would long continue to insist on prolonged and obviously unnecessarily expensive imprisonment for the sake of sheer retribution, vengeance, vindication of community norms, sadism, or expressivist reasons.

Free will believers and non-believers might divide over the involuntary or coerced medical cure of a criminal tendency before the person targeted had engaged in any actual criminal activity. Adherents to free will and dignity might well object to such a practice. But their opponents would likely have an easier time explaining why such a practice would be cost-effective than explaining why it would count as more genuinely humane by current progressive standards.

More generally, if we were to abolish free will considerations, we would have to confront the fact that some incarceration-related and death-penalty-related costs could be reduced only at the price of increases in the costs of crime, including reasonable fear of violent crime. Other current costs of the prison system may involve more or less wasteful expenditures with no linkage to either free will or its absence. ${ }^{160}$ And, yet, other costs, such as the sheer elaborateness of the current criminal and death penalty appeals processes, might well seem excessive and ripe for reduction if we do away with the ideas of free will, moral responsibility, basic dignity of the person, and the incomparable value of each life. Reforms might result in much fewer elaborate and costly appeals, a significant reduction in the time between pronouncing the death penalty and its imposition, various kinds of more or less painless surgeries and psychosurgeries, long-term sedation, or technologically exiling the non-dignified prisoner to a harmless, pleasant, illusory cyber-life - all with side effects on the prisoner deemed acceptable by the general public.

160. Policies, such as releasing a prisoner but denying that person genuinely effective and reasonably inexpensive anti-psychotic medications post-release, might seem to divide the free will and anti-free will camps. Such policies may reflect not only a vindictive spirit, but also a penny-wise, pound-foolish, or simply short-sighted public attitude that might erode if ordinary citizens better understood the actual cost tradeoffs involved. See David Lovell et al., Recidivism and Use of Services Among Persons with Mental Illness After Release from Prison, 53 PSY. CHIATRIC SERVS. 1290, 1290-96 (2002), available at http:/ / ps.psychiatryonline.org/article.aspx ?articleid $=87162$ (last visited Sept. 20, 2012). A similar argument might be raised in the case of in-prison treatment programs for addiction to illegal drugs, at least where the treatment program was obviously cost-effective. See Jessica Wapner, Giving Prisoners Addictive Drugs: Sometimes a Good ldea, THE ATLANTIC (Apr. 25, 2011, 12:34 PM), http://www.theatlantic.com/ health/archive/2011/04/giving-prisoners-addictive-drugs-sometimes-a-good-idea/237823/. 
More simply put, if our overall collective gratification and the pursuit thereof guides our criminal justice system, in addition to our collective dissatisfactions or frustrations and the avoidance thereof, unconstrained by considerations of free will and any notion of responsibility and human dignity dependent thereon, why would we consistently choose public policies that would be generous toward offenders we sensibly consider disproportionately unproductive, burdensome, dangerous, or risky-even after reasonable treatment-if that largely ineffective generosity came at the substantial sacrifice and ongoing long-term expense of the non-offending community? Each offender might indeed still be considered unique, in roughly the sense that individual snowflakes are thought to be unique. But a unique snowflake is not, thereby, of any significant net social value to anyone over time. Overall, the case for more or less abandoning free will and related notions as promoting a more humane, progressive, and civilized criminal justice systems seems doubtful in the extreme.

\section{CONCLUSION: THE QUESTION OF FORGIVENESS, MERCY, AND FREEDOM OF THE WILL}

Our collective attitudes toward a broad range of fundamental cultural matters, including, for example, various forms of equality and inequality, popular entertainment, religious belief and practice, and basic life choices, have evolved substantially over the past three centuries, if not over the past three decades. While our collective beliefs about free will and related ideas are not subject to change overnight-even for a single person, in all of his or her implications there is no obvious reason why what seems unthinkable today must remain unrealistic for the foreseeable future. ${ }^{161}$ Our main point herein has been that, despite all the increasing expert assumptions to the contrary, ${ }^{162}$ it is unlikely that largely abandoning our collective be-

161. Most poignantly, compare the generally skeptical view toward basic changes in attributing moral responsibility held by Professor P. F. Strawson, on the one hand, with the less skeptical view held by his son, Galen Strawson. Compare Peter Strawson, Freedom and Resentment, in PERSPECTIVES ON MORAL RESPONSIBILITY 45, 59-66 John Martin Fischer \& Mark Ravizza eds., 1993), with Galen Strawson, On "Freedom and Resentment," in PERSPECTIVES ON MORAL RESPONSIBILITY at 67, 97-100. On a related note, consider the rapid ascendance of belief in some form of physicalism. See David Papineau, Physicalism and the Human Sciences, PHIL. ONLINE IN CHINA (Dec. 23, 2008), http:/ / www.philosophyol.com/ pol $/ \mathrm{html} / 19 / \mathrm{n}-10019 . \mathrm{html}$ ("We are all physicalists now. It was not always so. . . This is a profound intellectual shift.").

162. See, e.g., Clarence Darrow's argument supra note 7 and accompanying text; see discussion supra notes 52-63; sources cited supra note 64 . 
lief in freedom of the will and its dependent and closely related notions would lead to a generally more humane, generous-spirited, and beneficent criminal justice system, at least by the free will skeptics' own current standards.

One loose end in particular, though, still deserves some attention. This issue is the complicated question of the meaning and scope of forgiveness and mercy in the criminal justice context. One might plausibly argue that, like proposals for basic systemic reforms of the economy, the ideas of forgiveness and mercy are subject to ideological abuse in the interests of the powerful, ${ }^{163}$ that the obligation of the criminal justice system is to dispense justice and not forgiveness or mercy, or that official forgiveness and mercy must inevitably be subjective, if not entirely arbitrary. ${ }^{164}$

But let us also remember that our exemplar of the progressive, humane determinist, Clarence Darrow, obviously thought extremely highly of official and private mercy, in their proper places. At the climax of his closing argument on behalf of Leopold and Loeb, Darrow declares:

I am pleading for the future; I am pleading for a time when hatred and cruelty will not control the hearts of men. When we can learn, by reason and judgment, and understanding and faith, that all life is worth saving, and that mercy is the highest attribute of man. ${ }^{165}$

Whether there would be a logical, as well as a practically useful, place for mercy and forgiveness in a criminal justice system that has largely abandoned the ideas of free will, moral responsibility, and the associated dignity of persons must depend upon the meaning we choose to give the terms in question. Consider, for example, the declaration that " $[\mathrm{m}]$ ercy is . . a free act of grace, love, or compassion, transcending the bounds of right and justice." 166 This does not sound especially naturalist. Or consider the view, obviously requiring the idea of basic human dignity, that forgiveness is the restora-

163. See generally PEIER Hay et al., Albion's FATAL TREE: CRIME AND SOCIETY IN EIGHTEENTH-CENTURY ENGLAND (Verso 2011) (1975).

164. See, e.g., Jeffrie G. Murphy, Mercy and Legal Justice, 4 SOC. PHIL. \& POL'Y 1, 9 (1986).

165. See Darrow, Closing Argument supra note 7, at 664 (emphasis added). See generally joSEPH Butler, Sermons VIII \& IX, in Fifteen Sermons Preached at the Rolls Chapel 137, 137-77 (1827) (discussing resentment and forgiveness of injuries); Eve Garrard \& David McNaughton, In Defence of Unconditional Forgiveness, 103 PROC. ARISTOTELIAN SOC'Y 39 (2003).

166. N.E. Simmonds, Judgment and Mercy, 13 OxFORD J. LEGAL STUD. 52,53 (1993) (discussing the idea that mercy is an "autonomous virtue," one never owed to anyone as a matter of right). 
tion of agape, or "a loving concern for the dignity of [people] conceived [of] as ends in themselves." ${ }^{167}$ More explicitly, J. Angelo Corlett recently argued that:

[I]f causal determinism is true in the hard deterministic sense, then there is no sense to be made of ethics and moral responsibility, and not even moral practices such as forgiving others makes much, if any, sense. For we only forgive those who are blameworthy for wrongful behavior, not those who could not have done otherwise .... So forgiving such "persons" seems to make little or no sense (if "persons" is not too flattering a term for them in a completely deterministic world). ${ }^{168}$

While it seems true that we neither morally blame nor meaningfully forgive, say, an erupting volcano or a ravenous foraging bear, some of those who reject freedom of the will maintain that the logic of forgiveness is still, in large measure, available. ${ }^{169}$ No doubt forgiveness could still be available in various thin senses-perhaps as merely changed behavior on the part of the forgiver, efforts to elevate the mood of the party forgiven, attempts to forget or render less salient certain events, changes in mood of the forgiver, or even as a particular kind of nudge or other manipulation toward more desired behavior. ${ }^{170}$

Perhaps the kinds of forgiveness and mercy that would remain logically available in the absence of free will and related ideas would indeed require some redefinition of these familiar terms. But, in the end, we would all still have to make some sort of evaluative judgment as to the role and importance of the kinds of forgiveness and mercy remaining available, within or without the criminal justice system.

The most general question we have asked above of the post-free will criminal justice system is this: assuming the system was purged as fully as possible of all moral blaming and any harshness resulting

167. R. S. Downie, Forgiveness, 15 PHIL. Q. 128, 133 (1965).

168. J. Angelo Corlett, Forgiveness, Apology, and Retributive Punishment, 43 AM. PHIL. Q. 25, 35 (2006). See generally ROSENBERG, supra note 32 . Note that we have throughout used the term "persons" in various, highly doubtful contexts merely for the sake of convenience and familiarity, even where it may rhetorically weaken the argument.

169. See, e.g., Derk Pereboom, Hard Incompatibilism, in Four VIEWS ON FreE WILL 85, 120 (2007). See generally PеREвоOM, supra note 57. For reviews of the latter, see generally Richard Double, Book Review, 67 Phil. \& Phenomenological Res. 494 (1993) and Carl Ginet, Book Review, 6 J. ETHICS 305 (2002).

170. See, e.g., Aurel Kolnai, Forgiveness, 74 Proc. ArISTOTELIAN SOC'Y 91, 104 (1973). 
therefrom, why would the system significantly risk or substantially sacrifice overall well-being - physical, psychological, or economic for the benefit of offenders similarly lacking in free will, the capacity for moral responsibility, the basic dignity of the person, and so forth? Why not, instead, say, mandate use of any available, cheap, mandatory, and pleasant high-tech tranquilizers and sedatives for offenders, psycho-surgery, or more or less harmless, cheap cyberexile whenever such treatment appears to most cost-effectively promote the public interest, coolly and dispassionately considered?

But this is not to deny that, under these assumptions and very different assumptions, certain forms of mercy and forgiveness (public and private) might legitimately pay off for all those involved. ${ }^{171}$ Forgiveness and mercy are, of course, not usually reducible to benevolently intended behavioral modification techniques, and they may well not be thought of as primarily manipulative or behavioraloutcome oriented. ${ }^{172}$ Thus, a post-free will criminal justice system may face the problem of the likely self-defeatingness of forgiveness and mercy, that even their targets may recognize as entirely aimed at socially desired behavioral results.

Consider the analogy of paying someone a compliment. A pure compliment may or may not implicate the past exercise of free will by the party being complimented. But, when we see through a compliment, well-intended or not, that is impure or a crude or subtle attempt to steer the complimented party's behavior along the complimenter's desired lines, the compliment is likely to be either completely ineffective or to backfire in some way. ${ }^{173}$

Absent free will and fundamental dignity, no one could logically react to manipulative forgiveness and mercy with genuine moral outrage and indignation. But it is not easy to see how such forgiveness and mercy would realistically have much transformative power for either the person or system doing the forgiving or for the party being forgiven. Forgiveness and mercy in that crucial sense

171. In the literary realm, consider the transformation, in not entirely materialist terms, of the thief Jean Valjean, made possible by a historic form of forgiveness and mercy. See VICTOR HuGO, LES MisÉRABLES, 103-06 (Lee Fahnestock \& Norman MacAfee trans., 1987) (1862). For a brief discussion, see Julia Kristeva \& Alison Rice, Forgiveness: An Interview, 117 PMLA 278, 286 (2002).

172. See Kolnai, supra note 170 , at 104 .

173. Of course, even assuming free will, many sincere acts of forgiveness, mercy, amnesty, or jubilee may lead to disastrous consequences, some would still argue for the moral value of any apparently reasonable such act, under assumptions of free will and the like, and that no backfiring could result from a correct perception by the person being genuinely forgiven of a manipulative intent or purpose. 
are not reducible to matters of anything like steering, manipulation, or adjusting incentives. Nor is it easy to see why the post-free will criminal justice system or a private party would even seek to engage in forgiveness and mercy, beyond whatever the optimal broadly cost-effective response to the offender might happen to be. Forgiveness and mercy post-free will beyond the otherwise rational broadly utilitarian response would seem to involve gratuitous, unnecessary, and unexplained risks and costs to the public.

It is of course impossible to be sure about the detailed operation of a future criminal justice system that has largely set aside free will and its related dependent notions. But we can easily say that Clarence Darrow's exalted estimation of the value of systemic mercy seems difficult to explain or "cash out" in such a system. ${ }^{174}$ 